\title{
Business Sector Innovation and Economic Growth: a Comparative Analysis between EU Countries
}

\author{
Cláudia Caseiro $^{1}$ | Marta Simões $^{1^{*}}$ \\ ${ }^{1}$ CeBER and Faculty of Economics, University of Coimbra, Portugal
}

\begin{abstract}
This paper examines the relationship between innovation carried out by the business sector and economic growth in the 28 member states of the European Union, divided into two groups ( 1 and 2) according to their innovation performance. We use fixed effects panel data methods to test the hypothesis that business sector innovation plays a relevant role in explaining the behaviour of real GDP per capita, estimating two growth regressions according to data availability (1990-2015 and 2008-2015; unrestricted/restricted sample). The results indicate that the role of business sector innovation in economic growth not only varies according to the sample of countries and the period under analysis but also the proxy for innovation used. In group 1 (above average innovation performance) the innovation indicators statistically significant in explaining growth also present a positive sign (with a few exceptions). In group 2 (below average innovation performance) on the other hand, the statistically significant business sector innovation indicators present a negative sign. One possible justification for these signs are differences in absorptive capacity so that the growth benefits of innovation activities depend on aspects such as human capital availability, accumulated knowledge, technological and financial support. Since group 1 includes countries with higher absorptive capacity, business sector innovation is effectively translated into faster economic growth. In group 2, innovation activities do not translate into productivity increases due to a lack of absorptive capacity. Additionally, resources used in innovation activities might compete with other activities more relevant in terms of the stage of the growth process these countries are in so that innovation saps growth
\end{abstract}

Key words: business sector innovation, economic growth, EU 28, fixed effects

JEL Classification: C23, 030, 047, 052

\section{INTRODUCTION}

There seems to be a consensus in the literature that innovation drives economic growth, supported both by the neoclassical theory of exogenous growth, but especially by endogenous growth models, pointing to technological progress and thus innovation as drivers of economic growth, albeit from different perspectives ((Solow, 1956); (Lucas, 1988); (Romer, 1990); (Jones, 1995); (Jones, 2005)). At the firm level, several studies examine the relationship between innovation carried out by firms with the respective productivity levels and growth (COECD, 2009); (Mohnen and Hall, 2013)). Eurostat data show that the intensity of R\&D expenditures in the 28 EU Member States (EU) increased between 2005 and 2014, with expenditure carried out by the business sector increasing from $1.10 \%$ of GDP in 2005 to $1.30 \%$ in 2014. Innovation

\footnotetext{
*Corresponding author, e-mail: mcsimoes@fe.uc.pt
} 
through $R \& D$ and investments in technology are considered essential to ensure competitiveness and increase productivity and in this way, sustain economic growth (Pece, 2015).

Innovation is however difficult to measure since it encompasses technological aspects, such as new or significantly improved products/ services, but also includes non-technological aspects, such as new organisational models, new marketing strategies, or new processes (Mohnen and Hall, 2013). The aim of this paper is to relate the different aspects of innovation by firms (technological and non-technological) to a country's long-term macroeconomic performance (economic growth), grouping the different countries under analysis according to different characteristics/indicators of their business sector innovation activity. In particular, we aim at better understanding the relationship between inputs and outputs of business innovation and the behaviour of output in different groups of countries. Following the identification of country groups based on the performance of indicators of inputs and outputs of innovation activities relative to the EU28 average, we estimate two empirical models that correspond to growth regressions where the different innovation indicators are the main explanatory variables taken alongside other relevant growth determinants. Depending on data availability, the period under analysis is $1990-2015$ or 2008-2015, for unrestricted and restricted country samples.

The remainder of the paper is organized as follows: after the introduction, the second section contains a brief review of the literature on the relationship between innovation and growth. In the third section, we analyse the average performance of firms' innovation activity in terms of inputs and outputs, grouping the countries under analysis according to their position relative to the EU28 average. The next section contains the methodology and results. In the final section, we present the main conclusions.

\section{INNOVATION AND GROWTH: THEORY AND EVIDENCE}

In the 1930s, Joseph Schumpeter highlighted that economic growth is caused by innovation, in particular, creative destruction, with business innovation fundamental for this change. (Solow, 1956) Also stresses that technological progress is the driver of growth, but does not provide an explanation how the decisions by economic agents in terms of input allocation between final goods production and innovation activities can influence the pace of economic growth. In the mid-1980s, endogenous growth theories assign knowledge a fundamental role in the explanation of technological progress. First-generation endogenous growth models consider innovation as an unintentional by-product of inputs accumulation, for instance through from learning by doing or learning by studying ((Romer, 1986); (Lucas, 1988)). Second-generation endogenous growth models, pose that decisions by firms concerning R\&D activities increase the respective productivity levels and also generate positive externalities in terms of productivity improvements in other firms, and, consequently, faster growth ((Romer, 1990); (Jones, 1995)).

There thus seems to be a consensus in the literature that technological progress and innovation are at the basis of economic growth, with many empirical studies presenting evidence on this link. For instance, (Ulku, 2004), using panel data to study the relationship between economic growth, R\&D expenditures and innovation in 20 OECD member states and 10 non-member countries, concludes that innovations (measured by patents) have a positive growth impact, although only developed OECD countries seem to be able to increase the level of innovation through R\&D expenditures. (Pradhan et al., 2016) studied 18 Eurozone countries over the period 1961-2013, using time series data. The dependent variable considered was the growth rate of real GDP per capita and the independent variables correspond to five indicators of innovation (number of patents per resident per thousand inhabitants, number of patents per non-residents per thousand inhabitants, number of patents per resident and non-resident per thousand inhabitants, real R\&D expenditures as a percentage of real GDP and researchers involved in R\&D activities per million inhabitants) and eight indicators of financial development. The authors conclude that financial development and innovation are important in determining 
economic growth and that long-term growth depends on countries' ability to innovate in order to remain competitive, which requires adequate (financial) resources devoted to R\&D activities. In a recent study, (Maradana et al., 2017) examined 19 EU member states and concluded that there is a long-run equilibrium relationship between the innovation indicators used (resident patents, non-resident patents, R\&D expenditures, R\&D researchers, high-tech exports, and scientific and technical journal articles) and growth.

However, despite the consensus on the importance of innovation for economic growth, many authors recognise that it is difficult to measure this concept, which hampers the results from empirical studies. Measuring innovation in a precise and rigorous way is critical to correctly assess its effect on growth (Hasan and Tucci, 2010). Often business innovation is not included in the analysis due to data availability and accessibility (microdata) issues (OECD, 2009). In addition, there is no unique and perfect measure of innovation.

According to (Hong et al., 2012), in practice, companies innovate in different ways: investing in $R \& D$, actively patenting, cooperating with external partners, acquiring technology externally via licensing, through design, marketing and staff training. It is, therefore, crucial to choose the adequate innovation proxies, although previous studies do not all point in the same direction concerning this choice. Several authors consider R\&D expenditures as a proxy for innovation, e.g. (Goel and Ram, 1994) and, more recently, (Freimane and Bālinga, 2016). But, according to (Wang, 2013), since (Schmookler, 1966) demonstrated the adequateness of patent data as an indicator of innovation, these have often been the preferred proxy for innovation. Similar to other authors, (Wang, 2013) considers that R\&D expenditures are only inputs to innovation activities and do not measure innovation results/outputs. The literature also distinguishes between two types of measurement of innovation: indirect and direct (Hong, Oxley and McCann, 2012). According to the authors, R\&D expenditures are indirect measures since they only measure inputs to innovation activities, while patents focus on the successful commercial application of innovations. However, (Hong, Oxley and McCann, 2012) consider that for econometric analysis the best option is to use direct measures, which may be objective (when it comes to the number of innovations or "count of innovations") or subjective.

The OECD Oslo Manual (OECD, 2005) identifies the existence of four different types of innovation: product, process, marketing and organisational. Product innovation refers to the "introduction of new or significantly improved goods or services concerning its intended characteristics or uses" ((OECD, 2005), p.57). Process innovation refers to the "implementation of a new or significantly improved production or distribution method" ((OECD, 2005), p.58). Marketing innovation refers to "implementing a new marketing method with significant changes in product design or packaging, product positioning, promotion or pricing" ((OECD, 2005), p.59). Finally, organisational innovation concerns the "implementation of a new organisational method in the company's business practices, in the organisation of its workplace or in its external relations" ((OECD, 2005), p.61).

At the firm level, several studies show a positive relationship between productivity and different types of innovation (Moreno and Surinach, 2014). Based on the former OECD classification, (Hall, 2011) concluded that there are significant impacts of product innovation on productivity, but, on the other hand, the impact of process innovations is more ambiguous and may even be negative. (Tavassoli and Karlsson, 2015) analysed the persistence of the innovation behaviour by firms and, similar to (Hall, 2011), concluded that the degree of persistence is not the same for all types of innovations, being greater for product innovations: product, process, and organizational innovations have a "true" dependency, that is, the decision to innovate in the next period is influenced by the success of the innovation of the previous period, while marketing innovations have a "false" dependency because the persistence effect does not remain in marketing innovations. (Mohnen and Hall, 2013) updated the previous research analysing the existing evidence on the effects of technological and non-technological innovations on the productivity of firms and the existence of potential complementarities between the different 
types of innovation. The authors concluded that all types of innovations contribute to improved productivity performance. (Moreno and Surinach, 2014) also sought to empirically analyse the relationship between the business sector innovation and productivity growth in 25 EU Member States, as well as in Iceland, Norway and Turkey for the period 1998-2000 and 2002-2004, concluding that innovation has a positive impact on productivity growth, but this impact is more important in the case of process innovations than output innovations, which can be justified on the basis that by introducing a new production process firms become more efficient, reducing costs and, thus, increasing productivity.

To sum up, it is consensual in the literature that innovation boosts economic growth and, from a business sector perspective, the introduction of innovations by firms, whether a product, process, organisational or marketing innovations, leads to an increase in the respective productivity, which should also lead to faster economic growth. The present studies contribute to the existing literature by carrying out a comprehensive analysis of the relationship between firms' innovation activity and economic growth taking into account a wide array of indicators (technological and non-technological) to measure business sector innovation (inputs and outputs).

\section{BUSINESS SECTOR INNOVATION IN THE EU28: A COMPARATIVE ANALYSIS}

In this section we differentiate the $28 \mathrm{EU}$ Member States in terms of the innovation activity carried out by the respective business sector (firms), grouping countries into different sets according to their average performance in terms of inputs and outputs, i.e. differences between innovation efforts/investments and the results of innovation activity for the countries under analysis, relative to the EU28 average.

The business sector innovation indicators related to inputs considered in this study are R\&D expenditures, innovation expenditures in the business sector, percentage of firms that promote the training of their employees, total staff in R\&D activities and researchers in R\&D activities. Outputs are represented by the following indicators: number of patent applications by the business sector to the European Patent Office (EPO), number of patents granted by the USPTO to the business sector, number of registrations of trademark applications, percentage of Small and Medium Enterprises (SMEs) that introduce product or process innovations, percentage of SMEs that introduce marketing or organizational innovations, percentage of SMEs that innovate internally, and percentage of innovative SMEs that cooperate with others. Table A.1 in the appendix summarises the indicators used, as well containing a detailed description and classification of each indicator according to the European Innovation Scoreboard (EIS) 2017.

The countries under analysis were grouped based on their average performance in terms of inputs and outputs of business sector innovation relative to the EU28 average for the period 2008-2015. We started by computing, for each country, the average indicator for the period 2008-2015. Next, we computed the ratios of each of these indicators relative to the EU28 average (EU28=100). Finally, in order to analyse the overall performance in terms of either inputs or outputs, we computed the average of the ratios for each of these two categories, based on the relative performance of each indicator. Four different groups were identified.

The first group of countries (group 1) is made up of countries with average performances above that of the EU28 in terms of both inputs and outputs of business sector innovation. This group comprises ten countries: Austria, Belgium, Denmark, Finland, France, Germany, Ireland, Luxembourg, the Netherlands and Sweden. In the EIS classification for 2015, these countries are classified as innovation leaders (Sweden, Netherlands, Luxembourg, Finland, Denmark, and Germany) and strong innovators (Ireland, France, Belgium, and Austria).

Figure 1 contains information on the relative performance of these member states in terms of inputs and outputs for the period 2008 to 2015 relative to the EU28 average. According to Figure 1, all these member states have higher performances in inputs and outputs compared to 
the EU28 average, with Finland, Sweden, Denmark, Austria, Germany and Luxembourg recording the highest ratios. However, this aggregate information masks different performances in terms of the various indicators used to measure inputs and outputs. Only Germany and Sweden perform above the EU28 in all indicators. The remaining member states have lower performances than the EU in some indicators. For instance, Austria, Belgium, Denmark, Finland, France, Ireland, Luxembourg and the Netherlands show levels of expenditure on innovation by the business sector (excluding R\&D) below the EU28 average. On the output side, Austria, Denmark and Luxembourg have performances above the EU28 average in all indicators, especially for registration of trademark applications in Luxembourg, an outlier. Belgium, Finland and France record lower than average trademark registrations applications, while in Ireland EPO performance is lower than average, as well as the trademark registrations applications ${ }^{1}$.

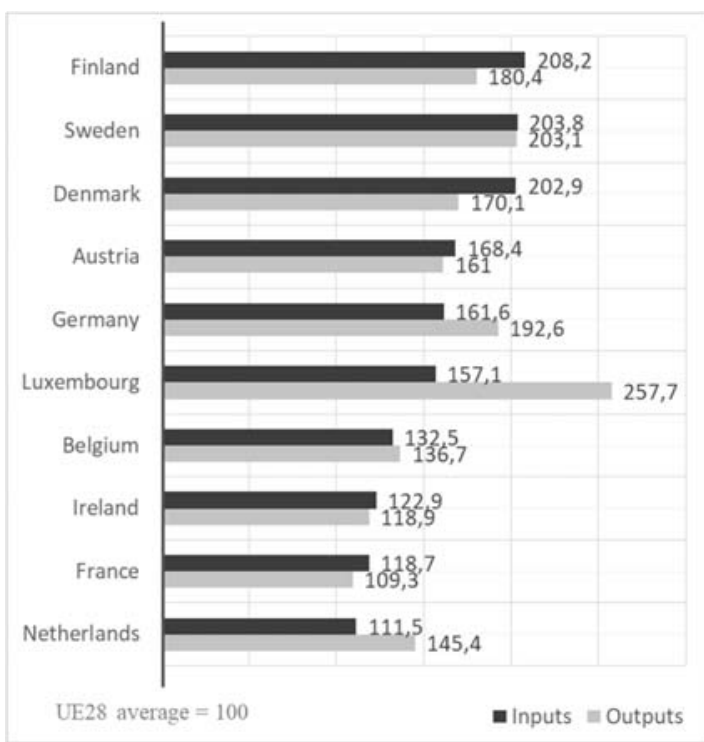

Figure 1. Group 1: inputs and outputs of business sector innovation relative to the EU28 average, 2008-15

Source: Own elaboration.

${ }^{1}$ The data for these more detailed indicators are available from the authors. 


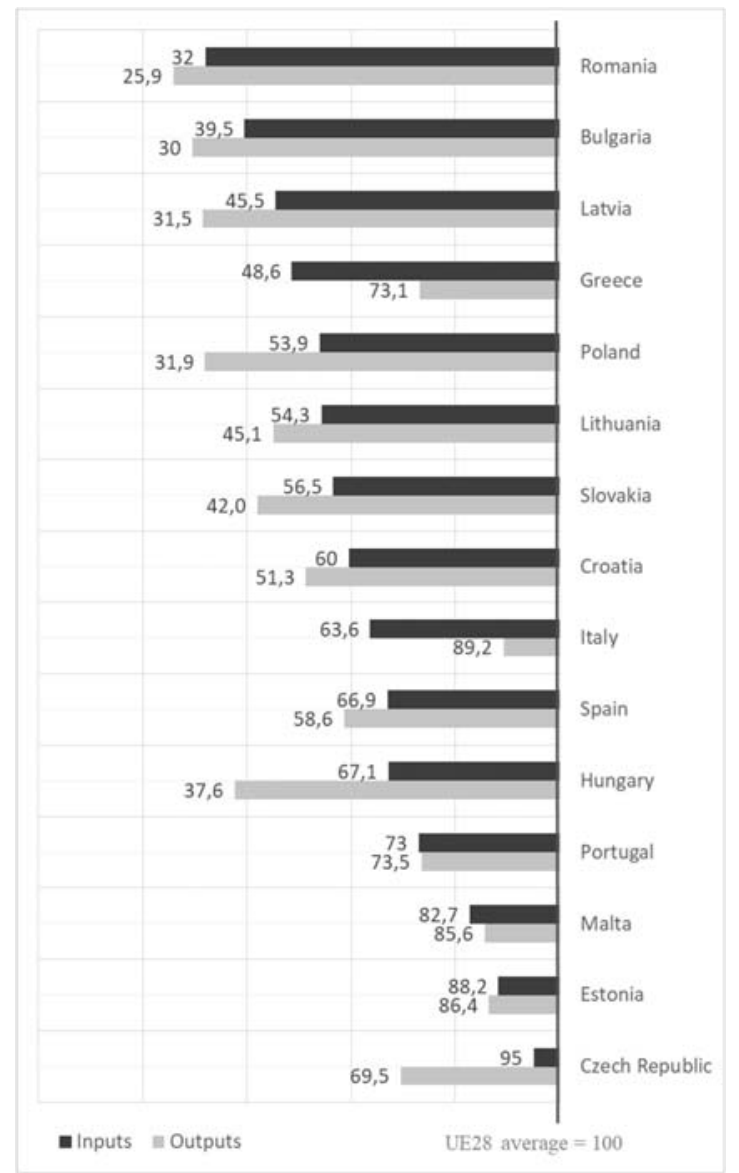

Figure 2. Group 2: inputs and outputs of business sector innovation relative to the EU28 average, 2008-15

Source: Own elaboration.

The second group of countries (group 2) includes member states which, on average, perform worse than the EU28 in terms of both inputs and outputs of business sector innovation. This group includes fifteen countries: Bulgaria, Croatia, Czech Republic, Estonia, Greece, Hungary, Italy, Latvia, Lithuania, Malta, Poland, Portugal, Romania, Slovakia and Spain. In the EIS typology for 2015, these member states are classified as modest innovators (Romania and Bulgaria), moderate innovators (Croatia, Czech Republic, Greece, Hungary, Italy, Lithuania, Latvia, Malta, Portugal, Poland, Slovakia and Spain) and, in the case of Estonia, a strong innovator. Figure 2 contains information on the inputs and outputs of this group 2 for the period 2008-2015 relative to the EU28 average. According to Figure 2, overall these countries have a performance in terms of inputs and outputs of business sector innovation below the EU28 average, although Romania, Bulgaria and Latvia stand out with levels of inputs and outputs which are more distant from the EU28 average than the other member states in this group.

On the other hand, the Czech Republic, Estonia and Malta record levels close to the EU28 average. Within this group, there are also substantial differences in the performance of certain indicators. For instance, the Czech Republic performs above the EU28 average in terms of R\&D activities personnel; Croatia, Slovakia, Estonia, Greece, Latvia, Lithuania, Malta, Poland and the Czech Republic record higher than average expenditure on innovation in the business sector; and in Croatia, Slovakia, Malta, Portugal and the Czech Republic the percentage of companies promoting employee training is also above average. For output indicators: trademark applications are above the EU28 average in Malta; the same applies to product and/or process 
innovations and the percentage of SMEs innovating internally in Estonia, Greece, Italy, Portugal and the Czech Republic and in marketing and/or organizational innovations in Greece, Italy, Portugal and the Czech Republic ${ }^{2}$.

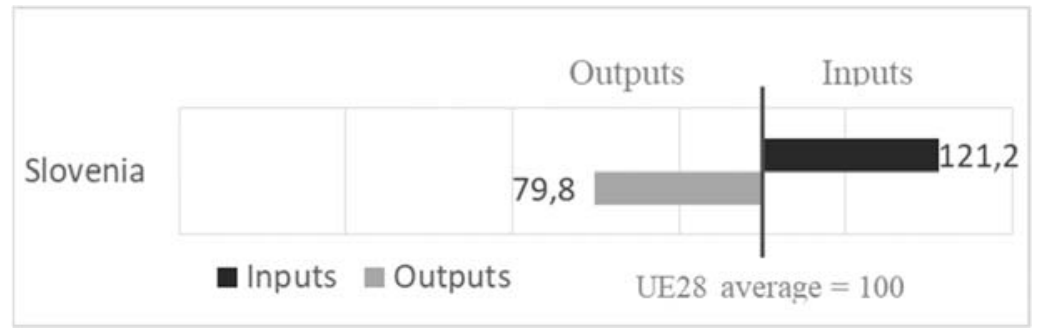

Figure 3. Group 3: inputs and outputs of business sector innovation relative to the EU28 average, 2008-15

Source: Own elaboration.

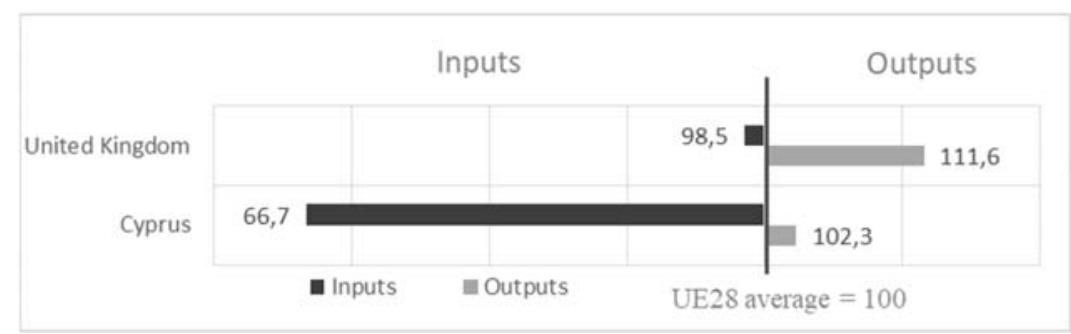

Figure 4. Group 4: inputs and outputs of business sector innovation relative to the EU28 average, 2008-15

Source: Own elaboration.

The third group (group 3) is characterised by higher than average inputs and at the same time lower than average outputs. This group consists only of Slovenia, classified by the EIS in 2015 as a strong innovator and its innovative activity is very close to the EU average. According to Figure 3 , the performance is higher than average for inputs (in three out of the five indicators and very close for the others), but below average for outputs. Slovenia performs well in most input indicators but records patent levels and registrations of brand applications well below the EU28 average.

Finally, the fourth group (group 4) includes countries with inputs below the EU28 average and outputs higher than the EU28 average. Two countries, Cyprus and the United Kingdom, are included in this group. According to the EIS in 2015, Cyprus is classified as a moderate innovator and the UK as a strong innovator. In figure 4, it is possible to see that in Cyprus the performance for inputs is lower than average, while outputs are slightly above the EU28 average. Cyprus records high innovation expenditures and percentage of firms that promote the training of officials and above the EU28 average, but low levels of patents (applications and concessions). In the United Kingdom inputs are close to the EU28 average, although slightly below, but the UK records a higher than average performance in three out of the five indicators. Outputs are below-average due essentially to trademark applications, the introduction of the product and/or process innovations, and the percentage of SMEs innovating internally (three out of seven indicators).

In the econometric analysis, since Slovenia has a large number of output indicators (four in seven) which are close to the EU28 average, this country will be included in group 1 . The United

${ }^{2}$ The data for these more detailed indicators are available from the authors. 
Kingdom will also be considered in group 1 as inputs are close to the EU28 average, while Cyprus will be included in group 2 since it performs poorly in inputs. These changes also make the groups more in line with the EIS classification.

\section{EMPIRICAL MODELS, METHODOLOGY AND RESULTS}

In this section, we present the two empirical models estimated, the methodology used and the main results obtained for the total sample as well as for the two groups defined in the previous section.

\section{Empirical Models}

In order to study the relationship between business sector innovation and economic growth, we consider the global sample of 28 EU Member States as well as the two country groups, 1 and 2 , defined in the previous section. Two periods were considered in the analysis due to data availability for some indicators of innovation activities: 1990-2015 (model 1) and 2008-2015 (model 2).

The first empirical model (model 1) is similar to that of (Moreno and Surinach, 2014), corresponding to an ad hoc growth regression, with variables measured at 5-year intervals, and is given by equation (1):

$$
\begin{aligned}
& \Delta \operatorname{lnGDPrpc} \operatorname{lit}_{i, t}=\delta_{0}+\delta_{1} \operatorname{lnGDPrpc}_{i, t-1}+\delta_{2} \text { GCF }_{i t}+\delta_{3} H C_{i, t-1}+\delta_{4} \text { Gov_cons }_{i t}+ \\
& \delta_{5} \text { Glob }_{i t}+\delta_{6} \text { INOV }_{i t}+\delta_{7} D 1+\delta_{8} D 2+u_{i t}
\end{aligned}
$$

where: $\delta_{0}$-Constant; $u_{i, t}$ - error term.; $\mathrm{i}$ - countries $(\mathrm{i}=1,2, \ldots, \mathrm{N}) . \mathrm{t}-5$-years sub periods $(\mathrm{t}=5)$; t-1 - initial year of each sub period.

The dependent variable in the first model, equation (1), is the annual growth rate of real GDP per capita in PPPs (Purchasing Power Parity) ( $\triangle \ln G D P r p c)$ for 5-years sub-periods. The data for this variable are from the Penn World Table 9.0 (Feenstra et al., 2015) and the World Bank ${ }^{3}$. The main explanatory variable of the model is INOV1 (proxy for the business sector innovation activity), and the proxies used, alternatively, are six indicators of business innovation (see table A.1 in the Appendix) that constitute measures of both inputs and outputs, selected based on their importance in explaining the relationship between business sector innovation and growth, as reported in previous literature ((Hasan and Tucci, 2010); (Hong, Oxley and McCann, 2012); (Wang, 2013)). We expect a positive sign for all the estimated coefficients, in line with the endogenous growth predictions of (Romer, 1990) and (Jones, 1995) and the results of studies such as (Freimane and Bāliṇa, 2016), (Hasan and Tucci, 2010) and (Wang, 2013).

The control variables included were selected from the theoretical and empirical growth literature (e.g. (Romer, 1986); (Barro and Sala-i-Martin, 2004); (Hasan and Tucci, 2010)). Initial real GDP per capita (InGDPrpc) is expected to deliver a negative estimated coefficient based on the convergence predictions of (Solow, 1956) and technology diffusion growth models (Weil, 2013) with poorer countries recording higher real GDP per capita growth rates. A positive relationship is expected between investment in physical capital $(G C F)$ and economic growth based on (Solow, 1956) and also between investment in human capital $(H C)$ and growth as this allows for higher production of new ideas/projects and the accumulation of knowledge, leading to higher productivity and (Romer, 1990)). Government consumption (Gov_cons) is expected to present a negative sign, assuming that these are non-productive expenditures: (Mitchel, 2005)

\footnotetext{
3 The data up to 2014 is from PWT 9.0 (Feenstra, Inklaar and Timmer, 2015), the values for 2015 were calculated based on per capita real GDP growth from the World Bank.
} 
argues that each monetary unit that the government spends means less money in the productive sector of the economy, which reduces the rate of output growth. The expected relationship between globalisation (Glob) and growth is ambiguous. According to (Samimi and Jenatabadi, 2014), globalisation allows countries to allocate resources more efficiently, as well as benefit from economies of scale and cost reductions, which leads to higher growth. On the other hand, globalisation has negative effects on growth in countries with weaker institutions and with political instability and also in countries specializing in activities that are not effective in the process of globalization.

The second empirical model (model 2) is given by equation (2):

$$
\begin{aligned}
& \Delta \operatorname{lnGDPrpc}_{i, t}=\delta_{0}+\delta_{1} \operatorname{lnGDPrpc}_{i, t-1}+\delta_{2} G C F_{i t}+\delta_{3} H C_{i, t-1}+\delta_{4} \text { Gov }_{-} \text {Cons }_{i t}+ \\
& \delta_{5} \text { Glob }_{i t}+\delta_{6} \text { INOV }_{i t}+\delta_{7} D 1+\delta_{8} D 2+u_{i t}
\end{aligned}
$$

where: $\delta_{0}$ - Constant; $u_{i, t}$ - error term.; i - countries $(\mathrm{i}=1,2, \ldots, \mathrm{N}) . \mathrm{t}-$ years $(2008-2015)$.

In model 2 the dependent and control variables are the same as those in model 1, although the proxy for human capital now corresponds to the percentage of the population aged 15 to 64 years old with upper secondary, non-tertiary post-secondary and higher education (tertiary) due data availability. The frequency of the data used is yearly since the innovation proxies related to SMEs (INOV2) are only available for a limited number of years, from 2008 until 2015. According to the studies reviewed, a positive relationship is expected between the various business sector innovation indicators and output growth ((OECD, 2009); (Hall, 2011); (Mohnen and Hall, 2013), (Moreno and Surinach, 2014)). However, different types of innovations are expected to have different quantitative impacts. The indicators of the different types of innovation used aggregate product and process innovations into a single indicator and marketing and organisational innovations in another. We thus expect that the former will have a more significant impact than the latter, but may not contribute to the explanation of economic growth due to the inclusion of process innovations, in light of the conclusions of (Hall, 2011) and (Moreno and Surinach, 2014). Marketing and organisational innovations might even have a negative impact on growth, according to (Tavassoli and Karlsson, 2015).

In both models 1 and 2 the variables $D 1$ and $D 2$ correspond to time dummies, included to consider the potential impact of the financial crisis on real GDP per capita growth. In model 1, D1 assumes the value 1 for the five-year period 2005-2010 and 0 otherwise; and variable D2 assumes the value 1 for the last five years (2010-2015) and 0 otherwise. In model 2, D1 assumes the value 1 for 2009, 2010, 2011 and 2012, 0 otherwise; and variable D2 assumes the value 1 for 2013, 2014 and 2015 and 0 otherwise.

\section{Methodology and results}

The empirical models were estimated using the econometric package Gretl version $2017 \mathrm{~d}$. As a preliminary analysis to determine the appropriate estimation method in a static panel context, we applied the usual diagnostic tests to choose between pooled OLS, fixed effects or random effects: the F-test, the Breusch-Pagan test (Breusch and Pagan, 1980) and the Hausman test (Hausman, 1978). The F-test allows one to choose between the pooled OLS and the fixed-effects methods: the null hypothesis (HO) considers homogeneity in the constant, so the pooled OLS method is the most adequate, against the alternative hypothesis (H1) that there is heterogeneity in the constant, so the most appropriate method, in this case, will be fixed effects. The BreuschPagan test, in turn, allows to decide between the pooled OLS method and the random effects method: HO considers the homogeneity in the constant, so the most appropriate method is pooled OLS; H1 admits heterogeneity between countries (not constant over time), so the random effects method is the most appropriate. Finally, the Hausman test allows to decide 
between fixed effects and random effects: HO considers heterogeneity across countries (not constant over time), so the random effects method is the most appropriate; H1 also considers heterogeneity across countries, but constant over time, so that the fixed effects method is the most appropriate. We performed these tests for the baseline specifications given by equations (1) and (2) and the alternative innovation indicators considering the whole sample of $28 \mathrm{EU}$ member states. According to the results for F-test, the fixed-effects method is preferable to the pooled OLS method. According to the Breusch-Pagan test, the random effects is the most appropriate. Finally, from the results of the Hausman test, we concluded that the fixed-effects method is preferable to the random-effects method. Overall these diagnostic tests thus indicate that the most appropriate estimation method for models 1 and 2 considering the whole sample is the fixed effects method. We also carried out the diagnostic tests for the sub-samples, groups 1 and 2, and both empirical models. For model 1, group 1, the most appropriate method is pooled OLS for all innovation indicators, except for Trademark_APP (fixed effects); when group 2 is considered, in model 1 the most appropriate methods are: random effects for RDEpc; pooled OLS for RD_Staff, RES_RD and Patent_APP; and fixed effects for Patent_G and Trademark_APP. For model 2, the fixed effects method is the most appropriate estimation method for groups 1 and $2^{4}$.

\section{Main results of the estimation of model 1}

Table 1 presents the results of the estimation of model 1 for the whole sample using fixed effects. In each column, a different indicator of business sector innovation is considered. Table A. 2 in the Appendix contains the results of the estimation for group 1 and table A. 3 contains the results for group 2 .

Regarding the control variables, the results obtained for the whole sample for $\operatorname{lnGDPrpc_{i,t-1}}$ confirm the predictions, negative and statistically significant coefficients in all columns, and thus the convergence predictions of (Solow, 1956) and technology diffusion models. These results also apply to groups 1 and 2. The estimated coefficients for the investment rate also confirm predictions when the EU28 or group 2 are considered, with a positive and statistically significant sign (except column V for EU28 and VI for group 1). The estimated coefficients for human capital for the EU28 are only statistically significant in columns II and V. In group 1 the estimated coefficients confirm the predictions, positive and statistically significant, except when trademark applications are used. For group 2, we obtain a negative (although not statistically significant) relationship between human capital and economic growth in columns I and VI. In the remaining cases, we get positive coefficients but not statistically significant. As for public consumption, some of the results are not in line with the predictions: for the EU28 the estimated coefficient is negative, but not statistically significant in columns I, II, III and V, it is positive but not statistically significant in column IV and negative and significant in column VI. When the sample is restricted to group 1, the results show that an increase in public consumption has a negative and statistically significant impact on the growth rate of real GDP per capita. When the sample is restricted to group 2, the results indicate that the relationship between public expenditure and growth is negative for columns I, II, III, IV and VI but not statistically significant. The results found for the EU28 show that the globalisation index has a positive and statistically significant impact on growth, supporting the predictions of (Samimi and Jenatabadi, 2014). These results continue to apply for groups 1 and 2, with a few exceptions. Overall, these results indicate that our growth regression is correctly specified since the majority of the results are in line with evidence from previous empirical growth studies.

Regarding the time dummy D1 (2005-2010), for the EU28 and the subsamples the majority of results show a negative (and generally statistically significant impact) on growth. As for the results with the time dummy D2 (2010-1015), for the EU28 and group 1, in general, the

\footnotetext{
${ }^{4}$ These results are available from the authors.
} 
estimated coefficient is not statistically significant, while for group 2 the coefficient is positive and usually statistically significant. These results indicate that the sovereign debt crisis period did not affect all the EU countries in the same way.

Turning now to the results for our main explanatory variables, when inputs of business sector innovation are used (R\&D expenditure, total R\&D staff and R\&D researchers), the results obtained with the EU28 (Table 1, columns I, II and III) indicate that these inputs do not contribute to growth over the period 1990-2015, since the respective estimated coefficients are not statistically significant. These results remain for group 1, as can be seen from Table A.2, columns I, II and III. The results obtained for group 2 (Table A.3) are different: an increase in total R\&D personnel and R\&D researchers has a negative and statistically significant effect, contrary to predictions. The lack of statistical significance for group 1 could be because these inputs, in reality, do not result in successful innovations, with economic value, and thus do not lead to productivity increases and faster growth. It could also be the case that there is a time lag between R\&D activities and innovations becoming effective (Wang, 2013). As for group $2^{5}$, these countries might be devoting R\&D expenditures to the imitation of innovations from developed countries that are not adequate to their reality and thus do not permit faster growth. According to (Galor, 2005), the growth process is characterized by different stages in terms of the relative importance of physical, human capital and knowledge accumulation, so countries in group 2 might be deviating scarce resources from more important activities as far as their stage in the growth process is concerned, which results in less growth.

When outputs of business sector innovation are introduced as the main explanatory variable (patent applications, patents granted and trademark applications registrations), the results for the EU28 (Table 1, columns IV, V and VI) show that there is a positive impact on growth, however, only trademark applications produce statistically significant effects 6 . For instance, patents do not contribute to the explanation of growth, contrary to the conclusions of authors like (Hasan and Tucci, 2010). This result can be due to a number of reasons, including that many innovations do not result in patens, in order to effectively remain secret and not be copied, so that technical details are not revealed; and also because some firms use patents to prevent other firms from placing an invention in the market (Hasan and Tucci, 2010); and finally, because the costs of patenting are high, becoming unfeasible for small firms (Wang, 2013). These results remain for group 1, according to table A.2, columns IV, V and VI. When the sample is restricted to group 2, the results obtained, as shown in Table A.3, columns IV, V and VI, are in general statistically significant (except patents granted). In the case of patent applications, the coefficient obtained is in line with the findings of (Hasan and Tucci, 2010): an increase in the number of patent applications produces positive and significant effects on the real GDP per capita growth rate.

On the other hand, contrary to predictions, registrations of trademark applications lead to a decrease in growth. Trademark application records are not associated with technology and are relevant to the services sector, according to the EIS (2017). In countries such as Bulgaria, Croatia, Hungary, Poland and Romania (transition countries) this indicator does not become relevant and may indicate that trademark registrations do not lead to productivity increases, as evidenced by the results of the estimation of the model leaving out the outliers Cyprus and Malta.

\footnotetext{
5 Consisting of some of countries considered by the IMF as developing countries: Bulgaria, Croatia, Hungary, Poland and Romania.

${ }^{6}$ Cyprus, Malta and Luxembourg represent outliers in the Trademark_APP indicator and were therefore withdrawn from the sample to check the impact on the results: trademark applications are no longer statistically significant in any of the samples under analysis, which may indicate that if the legal framework does not protect intellectual property, this indicator is not relevant for growth. These results are available from the authors.
} 
Looking at the AIC, BIC and HQ information criteria for the EU28 models in Table 1, we can conclude that the model that best explains growth is the model that considers patent applications since the criteria present the lowest value. The same applies for groups 1 and 2 (tables A.2 and A.3, respectively) 7 .

Table 1. Results of the estimation of model 1 (fixed effects), 28 EU countries, 1990-2015

\begin{tabular}{|c|c|c|c|c|c|c|}
\hline \multirow{2}{*}{$\begin{array}{l}\text { Explanatory } \\
\text { variables }\end{array}$} & \multicolumn{6}{|c|}{ Dependent variable - a Growth rate of real GDP per capita } \\
\hline & $\mathbf{I}$ & II & III & IV & $\mathbf{V}$ & VI \\
\hline Constant & $0.7386^{* * *}$ & $0.8976^{* * *}$ & $0.8894^{* * *}$ & $0.948 * * *$ & $1.1756^{* * *}$ & $1.1877^{* * *}$ \\
\hline InGDPrpci,t-1 & $\begin{array}{c}-0.0932 \\
* * *\end{array}$ & $\begin{array}{c}-0.1167 \\
* * *\end{array}$ & $\begin{array}{c}-0.1169 \\
* * *\end{array}$ & $-0.1249 * * *$ & $\begin{array}{c}-0.1456 \\
* * *\end{array}$ & $\begin{array}{c}-0.1297 \\
* * *\end{array}$ \\
\hline$G C F_{i, t}$ & $0.1891^{* * *}$ & $0.216^{* * *}$ & $0.2292 * * *$ & $0.2677^{* * *}$ & 0.0475 & $0.2278 * * *$ \\
\hline HCi,t-1 & 0.0042 & $0.00787^{*}$ & 0.00755 & 0.0060 & $0.00885 *$ & 0.000794 \\
\hline Gov_consi,t & -0.0744 & -0.0552 & -0.0434 & 0.0091 & -0.0191 & $\begin{array}{c}-0.3460 \\
* * *\end{array}$ \\
\hline$G l o b_{i, t}$ & $0.0019 * * *$ & $0.0023^{* * *}$ & $0.0024^{* * *}$ & $0.0025^{* * *}$ & $0.0027^{* * *}$ & $0.0018^{* * *}$ \\
\hline$R D E p c_{i, t}$ & $-1.0516 e^{-5}$ & - & - & - & - & - \\
\hline$R D \_$Staffi,t-1 & - & $-3.1771 \mathrm{e}^{-6}$ & - & - & - & - \\
\hline RES_RDi,t-1 & - & - & $-3.4140 \mathrm{e}^{-8}$ & - & - & - \\
\hline Patent_APP $P_{i, t}$ & - & - & - & 0.000121 & - & - \\
\hline Patent_G $G_{i, t}$ & - & - & - & - & 0.0001073 & - \\
\hline Trademark_APP $P_{i, t}$ & - & - & - & - & - & $\begin{array}{c}4.6620 \mathrm{e}^{-5} \\
* * *\end{array}$ \\
\hline$D_{1}$ & -0.00995 & -0.0111 & -0.0120 & $-0.0146^{*}$ & 0.000197 & -0.00953 \\
\hline$D_{2}$ & $0.0143^{*}$ & 0.0148 & 0.0135 & $0.0152 *$ & - & $0.0231 * *$ \\
\hline $\mathrm{LSDV} \mathrm{R}^{2}$ & 0.6097 & 0.6361 & 0.6369 & 0.6649 & 0.7718 & 0.6644 \\
\hline $\mathrm{R}^{2}$ dentro & 0.4591 & 0.5561 & 0.5429 & 0.6189 & 0.7437 & 0.5465 \\
\hline AIC (Akaike) & -635.3512 & -623.6562 & -605.0257 & -648.7218 & -554.6305 & -536.4121 \\
\hline BIC (Schwarz) & -531.8441 & -519.6036 & -502.0724 & -542.8226 & -459.4830 & -439.1948 \\
\hline Hannan-Quinn & -593.2916 & -581.3732 & -563.1937 & -605.6875 & -516.0262 & -496.9802 \\
\hline
\end{tabular}

Notes: Column I - R\&D expenditures; column II - total staff in R\&D activities; column III - researchers in R\&D activities; column IV - patent applications; column V - granted patents; column VI - registration of trademark applications. ${ }^{* *}, * * * *$ indicate statistical significance at the $1, \%$ and $10 \%$ levels, respectively.

Source: Own elaboration.

Taking the results as a whole, we can conclude these differ according to the group of countries and time period under analysis. Between 1990 and 2015, in the EU28 and group 1, inputs do not contribute to the explanation of aggregate output behaviour, while only R\&D personnel and R\&D

\footnotetext{
7 We also estimated model 1 with data for the period 2008-2015. The results obtained with the inputs indicators show that R\&D expenditures have a relevant role in explaining an increase in the growth rate of real GDP per capita, as predicted. The results with the outputs indicators are different depending on the sample under analysis. For the EU28, registrations of trademark applications are no longer statistically significant, with patents granted explaining economic growth. The coefficients obtained with outputs in group 1 show that patent applications and trademark application have significant negative and positive impacts, respectively. The results with outputs for group 2 show that patent applications in this period fails to explain the behavior of output. These results are available from the authors.
} 
researchers play a relevant role in explaining growth (but with a negative sign) in group 2. On the other hand, restricting the period to 2008-2015, R\&D expenditures present a positive and statistically significant role. As for outputs, between 1990 and 2015 trademark applications contribute to the explanation of growth due to the outliers Cyprus, Luxembourg and Malta (and also patent applications in group 2). Between 2008 and 2015, the results relative to the longer period change: for the EU28, patents granted have positive and relevant impacts on growth and brands lose their significance; for group 1, patent applications have negative and significant growth impacts; and for group 2 patent applications lose statistical significance.

\section{Main results of the estimation of model 2}

Table 2 presents the results of the estimation of model 2 for the EU28 with fixed effects considering each indicator of business sector innovation alternatively. Tables A.4 and A.5 in the Appendix contain the results for groups 1 and 2, respectively.

Concerning the control variables, according to Table 2 for the EU28 initial real GDP per capita presents a negative and statistically significant coefficient in all models (at the $1 \%$ level of significance), as expected, and the same applies for groups 1 and 2 (Tables A.4 and A.5, respectively). The results obtained for the investment rate are also as expected: we obtain a positive relationship and statistically significant for the EU28 and group 2. The relationship between human capital and the real per capita GDP growth rate for the EU28 and both groups 1 and 2 is positive and statistically significant. The results obtained for public consumption are negative and statistically significant for the EU28 and group 2. However, when the sample is restricted to group 1, the results are not statistically significant (some exceptions apply). Finally, as far as globalisation is concerned, the results are positive and statistically significant in the EU28 and group 2 as expected, but negative and not statistically significant in group 1.

The time dummy D1 (2009-2012) does not influence economic growth in the EU28 sample, so that the 2007-08 financial crisis shows no negative growth effects. However, the latter occurs in group 1, while in group 2 (Table A.5) the estimated coefficient is positive and statistically significant. The results for the time dummy D2 (2013-15) for the EU28 (Table 2) indicate that this was a post-crisis recovery period, with a positive and in most cases, statistically significant coefficient for D2. The coefficients obtained for group 1 (Table A.4) contrast with the previous ones since negative coefficients were obtained although without statistical significance.

Turning now to the results of the estimation of model 2 with inputs indicators (innovation expenditure and training of employees), the results obtained for the EU28 (Table 2, columns III and IV) show that only an increase in the percentage of firms that promote employee training contributes positively to growth. The results obtained for group 1 (table A.4, columns III and IV) remain the same. When the sample is restricted to group 2, the results indicate that no input indicator contributes to the explanation of the growth rate of real GDP per capita, as can be seen in table A.5, columns III and IV. The lack of statistical significance of innovation expenditure in group 1 can be justified by the relatively small investment in innovation in the form of dedicated machinery and equipment (within this group only Germany and Sweden have a ratio in this indicator that is higher than the EU average), which is not enough to spark innovation that promotes productivity improvements. For group 2, the lack of significance of innovation expenditure can be justified by the lack of absorptive capacity. This group includes transition countries with a low level of technological and scientific development, and thus, investments in innovation (equipment and machinery) do not translate into successful innovations. Additionally, the lack of statistical significance for the percentage of firms that promote training to develop/upgrade the ICT skills of employees for group 2 can be justified by the fact that this type of innovation input is more relevant in more advanced economies, according to the EIS Methodology Report 2017, so it does not translate into productivity gains in this second group. 
As for the results with indicators of outputs of business sector innovation (product/ process innovations, marketing/ organizational innovations, SMEs that innovate internally and SMEs that cooperate with others), the results reveal that for the EU28 all these indicators present negative coefficients, but only statistically significant for marketing and/or organizational innovations. The results for group 1 are not statistically significant. For group 2 (Table A.5, columns V, VI, VII and VIII), the results show that outputs have statistically significant negative effects on growth (except the percentage of SMEs that cooperate with others, without statistical significance). The lack of statistical significance of the outputs indicators for group 1, according to the EIS Methodology Report of 2017 lies on the fact that adoption of product and process innovations is especially relevant to the manufacturing industry and since the present study studies business sector innovation (which encompasses all business sectors, not only manufacturing), it is not enough to explain growth in this group of countries, especially because this is not the most important sector of activity in advanced countries. Another possible explanation, this time for the lack of significance of marketing/organisational innovations is that the adoption of new organisational methods requires a period of adaptation that often does not translate into success, because in many firms there is "resistance to change". Third, the lack of significance of cooperation activities related to innovation among group 1 firms could be explained by the fact that this type of activity has not enough relevance in the overall activities of the firms. On the other hand, a possible justification for the lack of relevance of cooperation activities between group 2 firms may be due to the fact that many cooperation agreements require complex innovation levels, which in the case of countries such as Bulgaria, Croatia, Hungary, Poland and Romania may not be successful as these countries lack human capital/more skilled workers. The negative impact of output indicators (product/ process innovations, marketing/ organizational innovations and SMEs that innovate internally) for group 2 may indicate that the resources devoted to innovation activities, such as skilled workers, may be necessary for other more fundamental activities in terms of the growth process of these countries, resulting in slower growth.

We also considered as explanatory variables exports of medium and high-tech products, exports of knowledge-intensive services and sales of new-to-firm and new-to-market innovations. The results for the EU28 countries and both country groups are not statistically significant (Tables 2, A.4 and A.5, columns I, II and IX, respectively). One possible justification for this lack of significance is that exports of these types of products and services are just a small share of total exports, and the same applies to sales of innovations as a share of total sales.

From the AIC, BIC and HQ information criteria for the different models using the EU28 (table 4), we conclude that the best model corresponds to the one considering the percentage of firms that promote employees training as the innovation variable. The same is true for group 1 (Table A.4). For group 2, the best model is the one using the percentage of SMEs that innovate internally (Table A.5).

Taking the results as a whole, again, the role of business sector innovation for growth differs according to the group of countries and the innovation indicator considered. In most cases for the EU28 and group 1, the results with inputs show that only employee training has a relevant (and positive) role; while for group 2 inputs do not have a growth effect. In terms of outputs, for the EU28 only marketing/organisational innovations have a significant (although negative) effect; for group 1 outputs do not play a relevant role and for group 2 product/ process innovations, marketing/organisational innovations and internally innovating companies have negative and significant impacts on economic growth. 
Table 2. Results of the estimation of model 2 (fixed effects), 28 EU countries, 2008-2015

\begin{tabular}{|c|c|c|c|c|c|c|c|c|c|}
\hline \multirow{2}{*}{$\begin{array}{l}\text { Explanatory } \\
\text { variables }\end{array}$} & \multicolumn{9}{|c|}{ Dependent variable - a Growth rate of real GDP per capita } \\
\hline & $\mathbf{I}$ & II & III & IV & $\mathbf{V}$ & VI & VII & VIII & IX \\
\hline Constant & $2.64^{* * *}$ & $2.66^{* * *}$ & $2.62^{* * *}$ & $2.71^{* * *}$ & $2.69^{* * *}$ & $2.76^{* * *}$ & $2.70^{* * *}$ & $2.66^{* * *}$ & $2.61^{* * *}$ \\
\hline $\operatorname{lnGDPrpcit-1}$ & $-0.3653^{* * *}$ & $\begin{array}{c}-0.3736 \\
* * *\end{array}$ & $\begin{array}{c}-0.369 \\
* * *\end{array}$ & $\begin{array}{c}-0.3839 \\
* * *\end{array}$ & $\begin{array}{c}-0.3737 \\
* * *\end{array}$ & $\begin{array}{c}-0.3868 \\
* * *\end{array}$ & $\begin{array}{c}-0.3753 \\
* * *\end{array}$ & $-0.3714^{* * *}$ & $\underset{* * *}{-0.3711}$ \\
\hline$G C F_{i . t}$ & $0.6476^{* * *}$ & $\underset{* * *}{0.6504}$ & $\underset{* * *}{0.6708}$ & $0.615^{* * *}$ & $\underset{* * *}{0.6615}$ & $\begin{array}{c}0.7029 \\
* * *\end{array}$ & $\begin{array}{l}0.6674 \\
* * *\end{array}$ & $0.6524^{* * *}$ & $\begin{array}{c}0.6389 \\
* * *\end{array}$ \\
\hline$H C_{i t-1}$ & $0.0094^{* * *}$ & $\begin{array}{c}0.0097 \\
* * *\end{array}$ & $\begin{array}{c}0.0095 \\
* * *\end{array}$ & $\begin{array}{c}0.0096 \\
* * *\end{array}$ & $\begin{array}{c}0.0097 \\
* * *\end{array}$ & $\begin{array}{c}0.0102 \\
* * *\end{array}$ & $\begin{array}{c}0.0099 \\
* * *\end{array}$ & $0.0097 * * *$ & $0.001^{* * *}$ \\
\hline Gov_cons $_{\text {i.t }}$ & $\begin{array}{c}-1.1774 \\
* * *\end{array}$ & $\begin{array}{c}-1.1703 \\
* * *\end{array}$ & $-1.081^{* * *}$ & $-1.218^{* * *}$ & $-1.124^{* * *}$ & $-1.149^{* * *}$ & $-1.1^{* * *}$ & $-1.16^{* * *}$ & $-1.19^{* * *}$ \\
\hline Glob $_{i, t}$ & $0.007^{* * *}$ & $0.007^{* * *}$ & $0.007^{* * *}$ & $0.007^{* * *}$ & $0.007^{* * *}$ & $0.007^{* * *}$ & $0.007^{* * *}$ & $0.007^{* * *}$ & $0.007^{* * *}$ \\
\hline Export_HT $T_{i . t}$ & -0.000518 & - & - & - & - & - & - & - & - \\
\hline Export_Servit. $_{\text {. }}$ & - & 0.000674 & - & - & - & - & - & - & - \\
\hline$I N O V_{-} E_{i . t}$ & - & - & -0.0121 & - & - & - & - & - & - \\
\hline TRAIN_EMP $P_{i, t}$ & - & - & - & $0.0032 * *$ & - & - & - & - & - \\
\hline ProdProc_INOV $_{i . t}$ & - & - & - & - & -0.000554 & - & - & - & - \\
\hline MarkOrg_INOV & - & - & - & - & - & $-0.0011^{*}$ & - & - & - \\
\hline$I N O_{-} S M E_{. t}$ & - & - & - & - & - & - & -0.0012 & - & - \\
\hline COOP_INOV $_{i, t}$ & - & - & - & - & - & - & - & -0.0002 & - \\
\hline Sales_INOV i.t $_{\text {. }}$ & - & - & - & - & - & - & - & - & 0.0008 \\
\hline$\overline{D_{1}}$ & 0.0106 & 0.0107 & 0.0085 & 0.0102 & 0.0105 & 0.0095 & 0.0095 & 0.0107 & 0.0103 \\
\hline$D_{2}$ & $0.0279^{*}$ & $0.0282 *$ & 0.026 & $0.0267^{*}$ & 0.0259 & 0.0251 & 0.024 & $0.0277^{*}$ & $0.0284^{*}$ \\
\hline $\mathrm{LSDV}^{2}$ & 0.6122 & 0.612 & 0.6155 & 0.6234 & 0.6127 & 0.6195 & 0.616 & 0.6118 & 0.6133 \\
\hline $\mathrm{R}^{2}$ within & 0.5437 & 0.5434 & 0.5475 & 0.5568 & 0.5442 & 0.5522 & 0.548 & 0.5431 & 0.5449 \\
\hline AIC (Akaike) & -765.103 & -764.99 & -766.73 & -770.81 & -765.33 & -768.79 & -766.99 & -764.87 & -765.64 \\
\hline BIC (Schwarz) & \begin{tabular}{|l|}
-647.09 \\
\end{tabular} & -646.98 & -648.72 & -652.80 & -647.32 & -650.78 & -648.98 & -646.85 & -647.62 \\
\hline $\begin{array}{l}\text { Hannan-Quinn } \\
(H Q)\end{array}$ & -717.33 & -717.2 & -718.95 & -723.03 & -717.56 & -721.02 & -719.21 & -717.09 & -717.86 \\
\hline
\end{tabular}

Notes: Column I - exports of medium and high-tech products; column II - exports of knowledge-intensive services; column III - innovation expenditures; column IV - training of employees; column V - product/ process innovations; column VI - marketing/ organizational innovations; column VII - \% of SMEs that innovate internally; column VIII -\% of SMEs cooperating with others; column IX - sales of innovations. ${ }^{* * *},{ }^{* *}$, * indicates that the coefficients are significant at 1, 5 and 10\% levels, respectively.

Source: Own elaboration.

\section{CONCLUSION}

This study investigates the relationship between business sector innovation and real GDP per capita growth in the 28 European Union member states using static panel data methods for the estimation of two growth regressions, assessing how inputs and outputs of firms' innovation activities play a role in economic growth and distinguishing between two groups of countries identified according to their innovation performance (above or below) relative to the EU28 average in terms of selected business sector innovation indicators.

The results obtained indicate that the role of business sector innovation in economic growth varies according to the sample of countries and the period under analysis, as well as according to the proxy used to measure business sector innovation activities. Overall, the innovation indicators that play a relevant role in explaining economic growth for group 1, the group with the highest innovation performance in the EU, have a positive impact on the growth rate of real 
GDP per capita, except patent applications (2008 -2015). On the other hand, group 2, characterized by below-average performances in business sector innovation, mainly presents indicators that have negative growth impacts $(R \& D$ personnel, $R \& D$ researchers and trademark registrations, product/ process innovations, marketing/ organizational innovations, and SMEs that innovate internally between), with the exception of patent applications for the 1990-2015 period and R \& D expenditure between 2008 and 2015. One possible justification for this divergence lies in absorptive capacity, which is associated with the level of development of countries, as the success of the innovations in terms of increasing productivity and generating faster growth depends on different aspects, namely human capital availability, accumulated knowledge, adequate infrastructure, technological and financial support/development. Group 1 includes the more developed member states (higher real GDP per capita) thus has in principle higher absorptive capacity, and so innovation in this group has more positive impacts, and higher business sector innovation indeed translates into faster growth.

On the other hand, group 2 includes less developed/transition member, so that innovations do not translate into productivity increases because they lack the necessary absorptive capacity. The negative growth impacts obtained could also be the result of competition for scarce resources between different types of activities, with different weights in the process of growth of these countries, with business sector innovation activities using resources that would have higher growth returns in other sectors of activity. The findings also allowed us to conclude that not all inputs and outputs of business innovation are relevant to the explanation of the behaviour of output in the $28 \mathrm{EU}$ member states, which again could be explained by the lack of certain types of absorptive capacity so that not all R\&D activities carried out translate into successful innovations.

In terms of policy implications, public policies can promote innovation through different instruments, e.g. either directly by providing funds, through human capital formation, enforcing patent protection laws, through tax benefits or indirectly through regulatory policies ((Griffith, 2000); (OECD, 2007)). Also, government policies can also provide incentives for firms to innovate. In light of the results obtained, the policy design should be different depending on the target group of countries. First, the results for the most recent period support policies that allow for an increase in R\&D expenditures in the business sector. For group 1, the results suggest that policies that promote the acquisition of machinery and equipment for R\&D activities are key to growth. For group 2, the results suggest that similar to (Pradhan, Arvin, Hall and Mahendhiran, 2016), policies must ensure an efficient allocation of resources, avoiding that innovation competes with other key sectors for resources. Besides, investment in innovation infrastructure is still necessary for business sector innovation to translate into productivity gains and higher growth.

Future research should focus on a deeper understanding of the differences in results across samples and periods, as well as between inputs and outputs of business sector innovation.

\section{REFERENCES}

Barro, R. J. \& Sala-i-Martin X. (2004). Economic Growth. Cambridge, Mass: MIT Press.

Barro, R. \& Jong-Wha L. (2013). A New Data Set of Educational Attainment in the World, 19502010. Journal of Development Economics, Vol. 104, pp. 184-198.

Breusch, T. \& Pagan, A. (1980). The Lagrange Multiplier Test and Its Applications to Model Specification in Econometrics. Review of Economic Studies, Vol. 47, pp. 239-253.

Feenstra, R.C, Inklaar, R. \& Timmer, M.P. (2015). The Next Generation of the Penn World Table. American Economic Review, Vol. 105, pp. 3150-3182.

Freimane, R. and Bālina S. (2016). Research and Development Expenditures and Economic Growth in the Eu: A Panel Data Analysis. Economics and Business, Vol. 29, pp. 5-11. 
Galor, 0. (2005). From Stagnation to Growth: Unified Growth Theory," P. Aghion and S. Durlauf, Handbook of Economic Growth. Elsevier: 171-293

Goel, R.K. \& Ram, R. (1994). Research and Development Expenditures and Economic Growth: A Cross-Country Study. Economic Development and Cultural Change, Vol. 42, pp. 403-411.

Griffith, R. (2000). How Important Is Business R\&D for Economic Growth and Should the Government Subsidise It? The Institute for Fiscal Studies Briefing Note No., 12.

Hall, B. H. (2011). Innovation and Productivity. NBER Working Paper No., 17178.

Hasan, I. and Tucci, C. L. (2010). The Innovation-Economic Growth Nexus: Global Evidence. Research Policy, Vol. 39, pp. 1264-1276.

Hausman, J. (1978). Specification Tests in Econometrics. Econometrica, Vol. 46, pp. 1251-1271.

Hong, S, Oxley L. \& McCann, P. (2012). A Survey of the Innovation Surveys. Journal of Economic Surveys, Vol. 26, pp. 420-444.

Jones, C. (2005). "Growth and Ideas," P. Aghion and S. Durlauf, Handbook of Economic Growth. Elsevier: 1063-111.

Jones, C. I. (1995). R\&D-Based Models of Economic Growth. Journal of Political Economy, 103(41): 759-84.

Lucas, R. (1988). "On the Mechanics of Economic Development." Journal of Monetary Economics, 22(1): 3-42.

Maradana, R. P., Rudra, P. P., Saurav, D., Kunal, G., Manju, J. \& Debaleena, C. (2017). "Does Innovation Promote Economic Growth? Evidence from European Countries." Journal of Innovation and Entrepreneurship, 6(1): 2-23.

Mitchel, D. J. (2005). "The Impact of Government Spending on Economic Growth." The Heritage Foundation Working Paper No., 1831.

Mohnen, P. \& Hall, B. H. (2013). "Innovation and Productivity: An Update." Eurasian Business Review, 3(1): 47-65.

Moreno, R. and Surinach, J. (2014). "Innovation Adoption and Productivity Growth: Evidence for Europe." Research Institute of Applied Economics Working Paper No., 2014/13.

OECD. 2007. Innovation and Growth: Rationale for an Innovation Strategy. Paris: OECD. . 2009. Innovation in Firms: A Microeconomic Perspective. Paris: OECD.

. 2005. Manual De Oslo: Diretrizes Para a Coleta E Interpretação De Dados Sobre Inovação Tecnológica. Paris: OECD.

Pece, A. M., Simona, O. E. O., Salisteanu, F. (2015). "Innovation and Economic Growth: An Empirical Analysis for Cee Countries." Procedia Economics and Finance, 26: 461-67.

Pradhan, R. P., Mak B. A., Hall, J.H. \& Nair, M. (2016). "Innovation, Financial Development and Economic Growth in Eurozone Countries." Applied Economics Letters, 23(16): 1141-44.

Romer, P. (1990). "Endogenous Technological Change." Journal of Political Economy, 98(5): S71102.

_. 1986. "Increasing Returns and Long-Run Growth." Journal of Political Economy, 94(5): 1002-

37.

Samimi, P., \& Jenatabadi, H.S. (2014). "Globalization and Economic Growth: Empirical Evidence on the Role of Complementarities." PLOS ONE, 9(4): e87824.

Schmookler, J. (1966). Invention and Economic Growth. Cambridge, MA.: Harvard University Press.

Solow, R. M. (1956). "A Contribution to the Theory of Economic Growth." Quarterly Journal of Economics, 70(1): 65-94.

Tavassoli, S. \& Karlsson, C. (2015). "Persistence of Various Types of Innovation Analyzed and Explained." Research Policy, 44: 1887-901.

Ulku, H. (2004). "R\&D, Innovation, and Economic Growth: An Empirical Analysis." International Monetary Fund Working Papers No., WP/04/185.

Wang, C. (2013). "The Long-Run Effect of Innovation on Economic Growth." Working Papers School of Economics, UNSW, Sydney No., 2052.

Weil, D. N. (2013). Economic Growth. Boston: Pearson/Addison Wesley. 


\section{APPENDIX}

Table A.1. Variables in the empirical models: description and sources

\begin{tabular}{|c|c|c|c|c|}
\hline & Variables & Model & Description & Source \\
\hline $\begin{array}{l}\text { Dependent } \\
\text { Variable }\end{array}$ & $\operatorname{lnGDPrpc} c_{i, t}$ & 1 e 2 & $\begin{array}{l}\text { Average real GDP growth rate per capita at constant } 2011 \\
\text { prices (USD) in PPPs }\end{array}$ & PWT \\
\hline \multirow{5}{*}{$\begin{array}{l}\text { Control } \\
\text { Variables }\end{array}$} & $\ln G D \operatorname{Prpci,t-1}$ & 1 e 2 & $\begin{array}{l}\text { Initial value of real GDP per capita at constant } 2011 \text { prices } \\
\text { (USD) in PPPs }\end{array}$ & PWT \\
\hline & $G C F_{i, t}$ & 1 e 2 & Gross Capital Formation as \% of GDP & PWT \\
\hline & $H C_{i, t-1}$ & 1 e 2 & $\begin{array}{l}\text { Average years of total schooling of the population aged } 15 \\
\text { and over }\end{array}$ & $\begin{array}{l}\text { (Barro } \\
\text { and Lee, } \\
2013 \text { ) }\end{array}$ \\
\hline & Gov_cons $_{i, t}$ & 1 e 2 & Public consumption as $\%$ of GDP & PWT \\
\hline & Glob $_{i, t}$ & 1 e 2 & Globalization index & KOF \\
\hline \multirow{5}{*}{$\begin{array}{l}\text { Investments/ } \\
\text { Inputs }\end{array}$} & $R D E p c_{i, t}$ & 1 & $\begin{array}{l}\text { R\&D expenditures in the business sector per capita (euros) - } \\
\text { source Eurostat }\end{array}$ & Eurostat \\
\hline & $I N O V_{-} E_{i, t}$ & 2 & $\begin{array}{l}\text { Expenditure on innovation (excluding R\&D) as \% of } \\
\text { turnover- source EIS }\end{array}$ & EIS \\
\hline & $T R A I N_{-} E M P_{i, t}$ & 2 & $\begin{array}{l}\text { Firms that promote training to develop or upgrade the ICT } \\
\text { skills of employees, \% of total firms- source EIS }\end{array}$ & EIS \\
\hline & RD_Staffi,t-1 & 1 & $\begin{array}{l}\text { Total staff in R\&D activities in the business sector per } \\
\text { million inhabitants- source PORDATA }\end{array}$ & PORDATA \\
\hline & $R E S \_R D_{i, t-1}$ & 1 & $\begin{array}{l}\text { Researchers in R\&D activities in the business sector per } \\
\text { million inhabitants- source PORDATA }\end{array}$ & PORDATA \\
\hline \multirow{7}{*}{$\begin{array}{l}\text { Innovation } \\
\text { Activities/ } \\
\text { Outputs }\end{array}$} & Patent_APP $P_{i, t}$ & 1 & $\begin{array}{l}\text { Number of patent applications to the EPO by the business } \\
\text { sector per million inhabitants- source Eurostat }\end{array}$ & Eurostat \\
\hline & Patent_G $G_{i, t}$ & 1 & $\begin{array}{l}\text { Patents Granted by the USPTO to the business sector per } \\
\text { million inhabitants- source Eurostat }\end{array}$ & Eurostat \\
\hline & Trademark_APP $P_{i, t}$ & 1 & $\begin{array}{l}\text { Number of European Union trademark applications (EUTM) } \\
\text { per million inhabitants- source Eurostat }\end{array}$ & Eurostat \\
\hline & ProdProc_INOV ${ }_{i, t}$ & 2 & $\begin{array}{l}\text { SMEs that introduce product or process innovations as \% of } \\
\text { the total number of SMEs- source EIS }\end{array}$ & EIS \\
\hline & MarkOrg_INOV & 2 & $\begin{array}{l}\text { SMEs that introduce marketing or organisational } \\
\text { innovations as \% of the total number of SMEs- source EIS }\end{array}$ & EIS \\
\hline & $I N O \_S M E_{i, t}$ & 2 & $\begin{array}{l}\text { SMEs that innovate internally as \% of the total number of } \\
\text { SMEs- source EIS }\end{array}$ & EIS \\
\hline & COOP_INOV $i, t$ & 2 & $\begin{array}{l}\text { Innovative SMEs that cooperate with others as \% of total } \\
\text { SMEs- source EIS }\end{array}$ & EIS \\
\hline \multirow{3}{*}{ Impacts } & Export_HT $_{i, t}$ & 2 & $\begin{array}{l}\text { Exports of Medium and High-Tech products as \% of total } \\
\text { exports of products }\end{array}$ & EIS \\
\hline & Export_servi,t & 2 & $\begin{array}{l}\text { Exports of knowledge-intensive services as \% of total } \\
\text { exports of services }\end{array}$ & EIS \\
\hline & Sales_INOV $i, t$ & 2 & $\begin{array}{l}\text { Sales of new-to-market and new-to-firm innovations as \% of } \\
\text { turnover }\end{array}$ & EIS \\
\hline \multirow{2}{*}{$\begin{array}{l}\text { Temporal } \\
\text { Dummies }\end{array}$} & $D_{1}$ & 1 e 2 & $\begin{array}{l}\text { Temporal Dummy } 1 \text { (Model 1: } 1 \text { for the period 2005-2010, } 0 \\
\text { otherwise; Model 2: } 1 \text { for 2009, 2010, } 2011 \text { and 2012, } 0 \\
\text { otherwise) }\end{array}$ & - \\
\hline & $D_{2}$ & 1 e 2 & $\begin{array}{l}\text { Temporal Dummy } 2 \text { (Model 1: } 1 \text { for the period 2010-2015, } 0 \\
\text { otherwise; Model 2: } 1 \text { for 2013, } 2014 \text { and 2015, } 0 \text { otherwise) }\end{array}$ & - \\
\hline
\end{tabular}

Source: Own elaboration based on data from the Penn World Table 9.0 (PWT), Barro-Lee dataset, KOF, Eurostat, European Innovation Scoreboard (EIS) and PORDATA. 
Table A.2. Results of the estimation of model 1, EU12 (group 1), 1990-2015

\begin{tabular}{|c|c|c|c|c|c|c|}
\hline \multirow{2}{*}{$\begin{array}{l}\text { Explanatory } \\
\text { variables }\end{array}$} & \multicolumn{6}{|c|}{ Dependent variable - a Growth rate of real GDP per capita } \\
\hline & $\mathbf{I}$ & II & III & IV & $\mathbf{V}$ & VI \\
\hline Constant & 0.1878 & 0.3344 & 0.2280 & 0.2510 & $0.5379^{* * *}$ & $1.5891^{* * *}$ \\
\hline $\ln G D P r p c i, t-1$ & -0.0280 & $-0.0429 *$ & -0.0318 & $-0.0330 *$ & $-0.0558 * * *$ & $-0.1572 * *$ \\
\hline$G C F_{i, t}$ & $0.2180^{* * *}$ & $0.1989 * *$ & $0.2118^{* * *}$ & $0.2170^{* * *}$ & 0.0284 & -0.1266 \\
\hline$H C_{i, t-1}$ & $0.0071^{* *}$ & $0.0076^{* *}$ & $0.0073 *$ & $0.0074^{* *}$ & $0.0055^{* *}$ & 0.0062 \\
\hline Gov_cons $i, t_{\text {_ }}$ & $-0.3376^{* *}$ & $-0.3975^{* * *}$ & $-0.3541^{* *}$ & $-0.3982 * * *$ & $-0.4278^{* * *}$ & $-0.9902 * * *$ \\
\hline Glob $_{i, t}$ & 0.000759 & 0.000856 & 0.000730 & 0.0006584 & $0.000858 * *$ & $0.0023 *$ \\
\hline$R D E p c_{i, t}$ & $-7.2578 \mathrm{e}^{-6}$ & - & - & - & - & - \\
\hline RD_Staffi,t-1 & - & $1.6809 \mathrm{e}^{-6}$ & - & - & - & - \\
\hline$R E S_{-} R D_{i, t-1}$ & - & - & $-1.2094 \mathrm{e}^{-7}$ & - & - & - \\
\hline Patent_APP $P_{i, t}$ & - & - & - & $2.3588 \mathrm{e}^{-5}$ & - & - \\
\hline Patent_G $G_{i, t}$ & - & - & - & - & $7.2195 \mathrm{e}^{-5}$ & - \\
\hline Trademark_APP $P_{i, t}$ & - & - & - & - & - & $9.4847 \mathrm{e}^{-5 * * *}$ \\
\hline$D_{1}$ & $-0.0238 * *$ & $-0.0231 * *$ & $-0.0238 * *$ & $-0.0251^{* * *}$ & -0.00999 & -0.0044 \\
\hline$D_{2}$ & 0.0103 & 0.0122 & 0.0104 & 0.0115 & - & $0.0406^{* * *}$ \\
\hline $\mathrm{R}^{2}$ & 0.3685 & 0.3703 & 0.3620 & 0.3851 & 0.5481 & - \\
\hline Adjusted R2 & 0.2654 & 0.2675 & 0.2534 & 0.2887 & 0.4690 & - \\
\hline $\mathrm{LSDV} \mathrm{R}^{2}$ & - & - & - & - & - & 0.8439 \\
\hline $\mathrm{R}^{2}$ within & - & - & - & - & - & 0.8131 \\
\hline AIC (Akaike) & -268.3492 & -268.5145 & -257.0800 & -278.4762 & -259.9794 & -255.5067 \\
\hline BIC (Schwarz) & -249.8052 & -249.9705 & -238.8518 & -259.6271 & -245.0097 & -218.0827 \\
\hline Hannan-Quinn & -261.1260 & -261.2912 & -250.0129 & -271.1033 & -254.3223 & -241.3641 \\
\hline
\end{tabular}

Notes: Column I - pooled OLS for R\&D expenses; column II - pooled OLS for the total staff in R\&D activities; column III - pooled OLS for researchers in R\&D activities; IV column - pooled OLS for patent applications; column V - pooled OLS for granted patents; column VI - fixed effects for the registration of trademark applications. ${ }^{* * *}, * *, *$ indicate statistical significance at the 1, 5 and 10\% levels, respectively.

Source: Own elaboration. 
Table A.3. Results of the estimation of model 1, EU16 (group 2), 1990-2015

\begin{tabular}{|c|c|c|c|c|c|c|}
\hline \multirow{2}{*}{ Explanatory variables } & \multicolumn{6}{|c|}{ Dependent variable - a Growth rate of real GDP per capita } \\
\hline & $\mathbf{I}$ & II & III & IV & $\mathbf{V}$ & VI \\
\hline Constant & $0.7373^{* * *}$ & $0.766124^{* * *}$ & $0.7719^{* * *}$ & $0.8930^{* * *}$ & $1.2841^{* * *}$ & $1.0914^{* * *}$ \\
\hline $\operatorname{lnGDPrpci,t-1}$ & $-0.0907^{* * *}$ & $-0.0948377^{* * *}$ & $-0.0953^{* * *}$ & $-0.1114^{* * *}$ & $-0.1640 * * *$ & $-0.1247^{* * *}$ \\
\hline$G C F_{i, t}$ & $0.2005^{* * *}$ & $0.179851^{* *}$ & $0.1692 * *$ & $0.2341^{* * *}$ & $0.1575^{*}$ & $0.3654^{* * *}$ \\
\hline$H C_{i, t-1}$ & -0.0013 & 0.000828091 & 0.000564 & 0.000264 & 0.0072 & -0.0066 \\
\hline Gov_cons $_{i, t}$ & -0.0507 & -0.103619 & -0.0979 & -0.0774 & 0.1050 & -0.0822 \\
\hline Glob $_{i, t}$ & $0.0021 * * *$ & $0.00226445^{* * *}$ & $0.0023 * * *$ & $0.0024^{* * *}$ & $0.0027^{* * *}$ & $0.0021^{* * *}$ \\
\hline$R D E p c_{i, t}$ & $1.0100 \mathrm{e}^{-5}$ & - & - & - & - & - \\
\hline$R D \_S t a f f i, t-1$ & - & $-8.6045 \mathrm{e}^{-6 *}$ & - & - & - & - \\
\hline$R E S_{-} R D_{i, t-1}$ & - & - & $-1.7627 \mathrm{e}^{-5 *}$ & - & - & - \\
\hline Patent_APP $P_{i, t}$ & - & - & - & $0.000463 *$ & - & - \\
\hline Patent_Gi,t & - & - & - & - & 0.000974 & - \\
\hline Trademark_APP $P_{i, t}$ & - & - & - & - & - & $-0.000138 * * *$ \\
\hline$D_{1}$ & -0.0078 & -0.0076 & -0.0053 & -0.0116 & 0.000567 & -0.0033 \\
\hline$D_{2}$ & $0.0136^{*}$ & $0.0151^{*}$ & $0.0176^{* *}$ & $0.0158 *$ & - & $0.0440^{* * *}$ \\
\hline $\mathrm{R}^{2}$ & - & 0.5639 & 0.5829 & 0.6404 & - & - \\
\hline Adjusted R ${ }^{2}$ & - & 0.5111 & 0.5308 & 0.5999 & - & - \\
\hline LSDV R ${ }^{2}$ & - & - & - & - & 0.8421 & 0.7133 \\
\hline $\mathrm{R}^{2}$ within & - & - & - & - & 0.8256 & 0.5628 \\
\hline AIC (Akaike) & -355.5393 & -348.6601 & -344.4415 & -370.7207 & -311.6848 & -313.4456 \\
\hline BIC (Schwarz) & -334.9252 & -327.8027 & -323.8274 & -349.2825 & -262.0305 & -262.3944 \\
\hline Hannan-Quinn & -347.3242 & -340.3319 & -336.2264 & -362.1255 & -292.1235 & -293.4016 \\
\hline
\end{tabular}

Notes: Column I - random effects for R\&D expenditure; column II - pooled OLS for the total staff in R\&D activities; column III - pooled OLS for researchers in R\&D activities; IV column - pooled OLS for patent applications; column $V$ - fixed effects for granted patents; column VI - fixed effects for the registration of trademark applications. ${ }^{* *},{ }^{* *}, *$ indicate statistical significance at the 1, 5 and 10\% levels, respectively.

Source: Own elaboration. 
Table A.4. Results of the estimation of model 2 with fixed effects, EU12 (group 1), 2008-15

\begin{tabular}{|c|c|c|c|c|c|c|c|c|c|}
\hline \multirow{2}{*}{$\begin{array}{l}\text { Explanatory } \\
\text { variables }\end{array}$} & \multicolumn{9}{|c|}{ Dependent variable - a Growth rate of real GDP per capita } \\
\hline & I & II & III & IV & $\mathbf{V}$ & VI & VII & VIII & IX \\
\hline Constant & $6.3944^{* * *}$ & $6.1876^{* * *}$ & $6.2550 * * *$ & $6.6236^{* * *}$ & $5.9766^{* * *}$ & $6.3595 * * *$ & $6.1626^{* * *}$ & $6.2453 * * *$ & $6.4380 * * *$ \\
\hline $\operatorname{lnGDPrpci,t-1}$ & $\begin{array}{c}-0.6641 \\
* * *\end{array}$ & $\begin{array}{c}-0.6421 \\
* * * \\
\end{array}$ & $\begin{array}{c}-0.6468 \\
* * *\end{array}$ & $\begin{array}{c}-0.6782 \\
* * * \\
\end{array}$ & $\begin{array}{c}-0.6270 \\
* * *\end{array}$ & $\begin{array}{c}-0.6540 \\
* * *\end{array}$ & \begin{tabular}{c|}
-0.6371 \\
$* * *$ \\
\end{tabular} & \begin{tabular}{c|}
-0.6451 \\
$* * *$
\end{tabular} & $\begin{array}{c}-0.6698 \\
* * * \\
\end{array}$ \\
\hline$G C F_{i, t}$ & 0.1869 & 0.1768 & 0.1598 & 0.1538 & 0.1521 & 0.1953 & 0.1735 & 0.1632 & 0.1516 \\
\hline$H C_{i, t-1}$ & $0.0134^{* * *}$ & $0.0130^{* * *}$ & $0.0133^{* * *}$ & $0.0121^{* * *}$ & $0.0132 * * *$ & $0.0129 * * *$ & $0.0130^{* * *}$ & $0.0131^{* * *}$ & $0.0135^{* * *}$ \\
\hline Gov_cons $_{i, t}$ & -0.7687 & -0.8443 & -0.8478 & $-0.8567^{*}$ & $-0.8805^{*}$ & -0.8466 & -0.8339 & -0.8067 & -0.7162 \\
\hline$G l o b_{i, t}$ & -0.0027 & -0.0024 & -0.00245 & -0.0027 & -0.0021 & -0.0023 & -0.0025 & -0.0025 & -0.0023 \\
\hline Export_HTi,t & 0.000739 & - & - & - & - & - & - & - & - \\
\hline Export_Servi,t & - & 0.000533 & - & - & - & - & - & - & - \\
\hline$I N O V_{-} E_{i, t}$ & - & - & 0.0068 & - & - & - & - & - & - \\
\hline TRAIN_EMP $P_{i, t}$ & - & - & - & $0.0029 * * *$ & - & - & - & - & - \\
\hline ProdProc_INOV $V_{i, t}$ & - & - & - & - & 0.0013 & - & - & - & - \\
\hline MarkOrg_INOV ${ }_{i, t}$ & - & - & - & - & - & -0.000365 & - & - & - \\
\hline$I N O \_S M E_{i, t}$ & - & - & - & - & - & - & 0.000327 & - & - \\
\hline COOP_INOV $i, t$ & - & - & - & - & - & - & - & 0.000559 & - \\
\hline Sales_INOV $V_{i, t}$ & - & - & - & - & - & - & - & - & 0.0016 \\
\hline$D_{1}$ & $-0.0306^{*}$ & $-0.0291^{*}$ & $-0.0294^{*}$ & $-0.0262 *$ & $-0.0292^{*}$ & $-0.0287^{*}$ & $-0.0294^{*}$ & $-0.0309^{*}$ & $-0.0318^{*}$ \\
\hline$D_{2}$ & -0.0074 & -0.0060 & -0.0066 & -0.0051 & -0.0034 & -0.0050 & -0.0062 & -0.0074 & -0.0091 \\
\hline LSDV R $^{2}$ & 0.6465 & 0.6457 & 0.6461 & 0.6848 & 0.6517 & 0.6465 & 0.6460 & 0.6466 & 0.6490 \\
\hline $\mathrm{R}^{2}$ within & 0.6284 & 0.6275 & 0.6279 & 0.6686 & 0.6338 & 0.6284 & 0.6279 & 0.6285 & 0.6310 \\
\hline AIC (Akaike) & -335.5293 & -335.3313 & -335.4253 & -345.1485 & -336.7694 & -335.5249 & -335.4088 & -335.5508 & -336.1278 \\
\hline BIC (Schwarz) & -286.9129 & -286.7150 & -286.8090 & -296.5322 & -288.1531 & -286.9085 & -286.7925 & -286.9345 & -287.5115 \\
\hline Hannan-Quinn & -315.9859 & -315.7879 & -315.8820 & -325.6051 & -317.2261 & -315.9815 & -315.8654 & -316.0074 & -316.5844 \\
\hline
\end{tabular}

Notes: Column I - exports of medium and high-tech products; column II - exports of knowledge-intensive services; column III - innovation expenditures; column IV - training of employees; column $V$ - product/ process innovations; column VI - marketing/ organizational innovations; column VII -\% of SMEs that innovate internally; column VIII - \% of SMEs cooperating with others; column IX - sales of innovations. ***, **, * indicate statistical significance at the 1, 5 and 10\% levels, respectively.

Source: Own elaboration. 
Table A.5. Results of the estimation of model 2 with fixed effects, EU16 (group 2), 2008-15

\begin{tabular}{|c|c|c|c|c|c|c|c|c|c|}
\hline \multirow{2}{*}{$\begin{array}{l}\text { Explanatory } \\
\text { variables }\end{array}$} & \multicolumn{9}{|c|}{ Dependent variable - a Growth rate of real GDP per capita } \\
\hline & $\mathbf{I}$ & II & III & IV & $\mathbf{V}$ & VI & VII & VIII & IX \\
\hline Constant & $2.5022 * * *$ & $2.4888^{* * *}$ & $2.4548^{* * *}$ & $2.5312^{* * *}$ & $2.6043^{* * *}$ & $2.4820 * * *$ & $2.2812^{* * *}$ & $2.5214^{* * *}$ & $2.4941^{* * *}$ \\
\hline $\operatorname{lnGDPrpcit-1}$ & $\begin{array}{c}-0.3670 \\
* * * \\
\end{array}$ & $\begin{array}{c}-0.3681 \\
* * * \\
\end{array}$ & $\begin{array}{c}-0.3675 \\
* * * \\
\end{array}$ & $\begin{array}{c}-0.3746 \\
* * * \\
\end{array}$ & $\begin{array}{c}-0.3829 * * \\
* \\
\end{array}$ & $\begin{array}{c}-0.3840 \\
* * * \\
\end{array}$ & $\begin{array}{c}-0.3538 \\
* * * \\
\end{array}$ & \begin{tabular}{|c|}
-0.3716 \\
$* * *$
\end{tabular} & $\begin{array}{c}-0.3704 \\
* * * \\
\end{array}$ \\
\hline$G C F_{i, t}$ & $0.7714^{* * *}$ & $0.7674^{* * *}$ & $0.7924^{* * *}$ & $0.7502^{* * *}$ & $0.8471^{* * *}$ & $0.8735^{* * *}$ & $0.8341^{* * *}$ & $0.7757^{* * *}$ & $0.7662^{* * *}$ \\
\hline$H C_{i, t-1}$ & $0.0088^{* * *}$ & $0.0089^{* * *}$ & $0.0089^{* * *}$ & $0.0087^{* * *}$ & $0.0094^{* * *}$ & $0.0109^{* * *}$ & $0.0103^{* * *}$ & $0.0088^{* * *}$ & $0.0090^{* * *}$ \\
\hline Gov_consi,t & $\begin{array}{c}-1.2168 \\
* * *\end{array}$ & $\begin{array}{c}-1.2079 \\
* * *\end{array}$ & $\begin{array}{c}-1.1076 \\
* * *\end{array}$ & $\begin{array}{c}-1.2289 \\
* * *\end{array}$ & $\begin{array}{c}-0.9851 \\
* * *\end{array}$ & $\begin{array}{c}-1.1182 \\
* * *\end{array}$ & $\begin{array}{c}-0.8771 \\
* *\end{array}$ & $\begin{array}{c}-1.2014 \\
* * *\end{array}$ & $\begin{array}{c}-1.2349 \\
* * *\end{array}$ \\
\hline$G_{l o b} b_{i, t}$ & $0.0086^{* * *}$ & $0.0087^{* * *}$ & $0.0088^{* * *}$ & $0.0088^{* * *}$ & $0.0085^{* * *}$ & $0.0092^{* * *}$ & $0.0080^{* * *}$ & $0.0087^{* * *}$ & $0.0087^{* * *}$ \\
\hline Export_HT $H, t$ & $\begin{array}{c}-0.00029 \\
6 \\
\end{array}$ & - & - & - & - & - & - & - & - \\
\hline Export_Servi,t & - & $\begin{array}{c}-0.00011 \\
8 \\
\end{array}$ & - & - & - & - & - & - & - \\
\hline$I N O V_{-} E_{i, t}$ & - & - & -0.0108 & - & - & - & - & - & - \\
\hline TRAIN_EMP $P_{i, t}$ & - & - & - & 0.0017 & - & - & - & - & - \\
\hline $\begin{array}{l}\text { ProdProc_INOV } \\
t\end{array}$ & - & - & - & - & $-0.0024^{* *}$ & - & - & - & - \\
\hline MarkOrg_INOV ${ }_{i, t}$ & - & - & - & - & - & $\begin{array}{c}-0.0019 \\
* *\end{array}$ & - & - & - \\
\hline$I N O \_S M E_{i, t}$ & - & - & - & - & - & - & $-0.0030^{* *}$ & - & - \\
\hline COOP_INOV $i, t$ & - & - & - & - & - & - & - & $\begin{array}{c}-0.00040 \\
6 \\
\end{array}$ & - \\
\hline Sales_INOV $V_{i, t}$ & - & - & - & - & - & - & - & - & 0.000465 \\
\hline$D_{1}$ & $0.0297^{* *}$ & $0.0295^{* *}$ & $0.0272 *$ & $0.0292 * *$ & $0.0316^{* *}$ & $0.0256^{*}$ & 0.0233 & 0.0301 ** & 0.0297 ** \\
\hline$D_{2}$ & $0.0415 *$ & $0.0408 *$ & $0.0393 *$ & $0.0417^{*}$ & 0.0351 & 0.0312 & 0.0247 & $0.0416^{*}$ & $0.0424^{*}$ \\
\hline $\mathrm{LSDV} \mathrm{R}^{2}$ & 0.6666 & 0.6665 & 0.6704 & 0.6696 & 0.6839 & 0.6845 & 0.6891 & 0.6665 & 0.6670 \\
\hline $\mathrm{R}^{2}$ within & 0.5830 & 0.5828 & 0.5877 & 0.5867 & 0.6046 & 0.6054 & 0.6112 & 0.5829 & 0.5835 \\
\hline AIC (Akaike) & $\begin{array}{c}-440.920 \\
8 \\
\end{array}$ & $\begin{array}{c}-440.866 \\
5 \\
\end{array}$ & $\begin{array}{c}-442.196 \\
1 \\
\end{array}$ & $\begin{array}{c}-441.925 \\
8 \\
\end{array}$ & -446.8741 & $\begin{array}{c}-447.105 \\
2 \\
\end{array}$ & $\begin{array}{c}-448.748 \\
6 \\
\end{array}$ & $\begin{array}{c}-440.899 \\
3 \\
\end{array}$ & $\begin{array}{c}-441.063 \\
7 \\
\end{array}$ \\
\hline BIC (Schwarz) & $\begin{array}{c}-375.676 \\
8 \\
\end{array}$ & $\begin{array}{c}-375.622 \\
5 \\
\end{array}$ & $\begin{array}{c}-376.952 \\
1 \\
\end{array}$ & $\begin{array}{c}-376.681 \\
9 \\
\end{array}$ & -381.6301 & $\begin{array}{c}-381.861 \\
3 \\
\end{array}$ & $\begin{array}{c}-383.504 \\
6 \\
\end{array}$ & $\begin{array}{c}-375.655 \\
3 \\
\end{array}$ & $\begin{array}{c}-375.819 \\
8 \\
\end{array}$ \\
\hline Hannan-Quinn & $\begin{array}{c}-414.449 \\
2 \\
\end{array}$ & $\begin{array}{c}-414.395 \\
0 \\
\end{array}$ & $\begin{array}{c}-415.724 \\
5 \\
\end{array}$ & $\begin{array}{c}-415.454 \\
3 \\
\end{array}$ & -420.4026 & $\begin{array}{c}-420.633 \\
7 \\
\end{array}$ & $\begin{array}{c}-422.277 \\
0 \\
\end{array}$ & $\begin{array}{c}-414.427 \\
7 \\
\end{array}$ & \begin{tabular}{|c|}
-414.592 \\
2 \\
\end{tabular} \\
\hline
\end{tabular}

Notes: Column I - exports of medium and high-tech products; column II - exports of knowledge-intensive services; column III - innovation expenditures; column IV - training of employees; column V - product/ process innovations; column VI - marketing/ organizational innovations; column VII -\% of SMEs that innovate internally; column VIII - \% of SMEs cooperating with others; column IX - sales of innovations. ***,**, * indicate statistical significance at the 1, 5 and $10 \%$ levels, respectively.

Source: Own elaboration.

\begin{tabular}{l|l} 
Article history: & Received: November 8, 2018
\end{tabular}

Accepted: May 30, 2019 


\title{
Comparative Analysis of Insurance Premiums in Serbia and Bosnia and Herzegovina - Multiple Linear Regression Analysis Model
}

\author{
Tijana Kaličanin $^{1 *}$ | Sandra Kamenković ${ }^{1}$ | Ivana Simeunović ${ }^{1}$ \\ 1 University Union, Belgrade Banking Academy - Faculty of Banking, Insurance and Finance, Belgrade, Serbia
}

\begin{abstract}
In the last few years, the global insurance market has shown a trend of concentration growth, which was conditioned by the processes of mergers and acquisitions in insurance. The aim of this paper is to make a comparative analysis of insurance premiums in Serbia and Bosnia and Herzegovina. Dynamic analysis of market concentration indicators calculated on the basis of absolute amounts of premiums indicates that the insurance market in Bosnia and Herzegovina is characterized by low concentrated supply, i.e. there is greater equality of market share in relation to high inequality and high concentration among market participants in the insurance sector of the Republic of Serbia. Having applied the multi-linear regression model in order to analyze the impact of selected macroeconomic indicators on the amount of insurance premiums in the period 2000-2017, it can be concluded that the greatest impact on the amount of the premium in Bosnia and Herzegovina had Gross Domestic Income and Wage and Salaries Workers. In the Republic of Serbia, the greatest influence on the amount of premium in the observed period had the Average Net Salary, Households and Final Consumption Expenditure and Gross Domestic Income.
\end{abstract}

Key words: insurance premiums, insurance sector, multiple linear regression analysis model

JEL Classification: C30, G22, L19

\section{INTRODUCTION}

In the last two decades, countries of Central and East Europe have experienced tremendous changes in the political, cultural, social and economic environment. Central and East European financial system has been rapidly developing during the last couple of years, contemporary regulations have been introduced and new financial institutions have been established contributing to the maintenance of macroeconomic stability in the region. Nonetheless, the macroeconomic sector in the region, underdeveloped even before the recession took place, has been a highly risky place for investments and unstable in comparison with Western Europe (Kaličanin \& Hanić 2016a). The insurance market in the Western Balkans is characterized by significant changes caused by different economic growth pace. Countries preparing to become members of the European Union are carrying out faster reforms, and there is also a significant inflow of foreign capital due to a reduction of financial and political risks (Novović-Burić et al. 2017).

In this paper, the insurance sectors were analyzed in the Republic of Serbia and Bosnia and Herzegovina. In addition to the transition process in both countries, these countries have

\footnotetext{
*Corresponding author, e-mail: tijana.kalicanin@bba.edu.rs
} 
undergone similar political and economic changes in the past decade. Both insurance markets have passed through the process of integration and internationalisation. In addition to many similarities characteristic for these two markets, there are substantial differences that are reflected in the number of residents, the number of insurance companies, the market structure, the participation of the market leader, and the number of companies with foreign capital.

The market of a country is as developed as its competition is able to function on it. Competition has to be constantly stimulated and protected by mechanisms in line with the European integration processes and policy focused on market economy development. Competition as such has been a particularly sensitive issue in transitional countries such as

Serbia and countries in the region. Changing the number of insurance companies on the market influenced significantly the formation of a group of leaders in the insurance market as well as strengthening the position and increasing the individual market share of the leader (Kaličanin \& Lazić, 2018).

Initial structural changes raised an issue and brought about the need for a higher competitiveness in Serbia. Every country aspiring to join the EU and integration processes ought to develop legal norms and apply the EU regulations (Kaličanin \& Hanić 2016a). In recent years, the insurance sector has become a significant factor in the development of the overall financial and economic system. In the first part of the paper, insurance markets and level of competitiveness were analyzed. Competitiveness in the market has led to changes in the balance sheet structure of the entire financial sector as well as the position of individual insurance companies in previous years. The insurance sector is extremely important for the economy of a country, not only from the point of view of security and protection from different types of risks but also from the point of view of the overall economic development and improvements in the functioning of the financial market. In the second part of the paper, the focus is on the analysis of insurance premiums and the impact of selected macroeconomic indicators on premiums using the multi-linear regression model.

\section{LITERATURE REVIEW}

There are many analyses which deal with insurance premiums and economic growth. Outreville (1990), Zhi (1998), Beck and Webb (2003), Webb et al. (2002) have shown a very strong interaction between insurance premiums and GDP despite different periods and country patterns. Analyses mainly suggest that higher GDP growth rates have an impact on economic activity growth, which leads to assumptions about a positive correlation between GDP growth rate and demand for insurance.

Haiss and Sumegi presented very extensive research in 2008, which led to the conclusion that there is a correlation between insurance and GDP growth in EU-15 countries with developed financial markets as well as short-term linkages between GDP and non-life premiums on a sample of CEE countries. Serbia and Bosnia and Herzegovina are selected for this research because very few authors have analyzed this region from the insurance aspect.

Novovic-Buric et al. (2017) explored the influence of certain factors on the purchase of insurance products through a panel analysis. Western Balkan countries were analyzed in the period from 2005 to 2015, and the results show that most of the economic factors affect total life premiums. The demand for life insurance has a significant and positive impact on GDP and wages, while the influence of unemployment and interest rates is negative.

Dragos (2014) used the fixed and random effects model in the analysis, which entailed 17 countries in Asia and Central Eastern Europe. The aim was to compare emerging markets in Europe characterised by market economies and emerging markets in Asia, which are predominantly planned economies in terms of the impact of economic performance on life and non-life insurance. It has been noted that the differences certainly exist. The results concerning the CEE, taking into consideration the countries which are analyzed in this research have shown 
that income and education have a positive impact on the insurance demand, while urbanisation has shown a significant impact on non-life insurance. On the other hand, income distribution negatively influences the demand for insurance.

Kjosevski (2012) analysed the determinants of life insurance demand in Central and Southeastern Europe by using fixed-effect panel models in the period 1998-2010. The results show that in terms of life insurance, the most significant predictors are the following: high GDP per capita, inflation, health expenditure, level of education and the rule of law.

Mitra (2017) analysed the impact of economic, demographic and cultural factors on life insurance consumption in $28 \mathrm{EU}$ countries. The focus was on the emerging East European economies, given that in the analysed period 2009-2014, there were significant reforms of the insurance sector in these countries. The results show that the higher GDP is an indicator of higher wages and higher levels of economic activity, the more positive impact on insurance demand.

Ward and Zurbruegg (2002) analysed 37 countries in the period 1987 - 1998 with the intention to point to the links between insurance premiums and various legal and political factors, as well as economic and social factors. The analysis has shown that the consumption of life insurance products is under stronger influence of GDP in Asia than in OECD countries, which is an expected result given that in the OECD countries there is a considerably higher average income level and that 'S curves' suggest that at higher levels of income the demand for insurance is less susceptible to the revenue growth.

Bianchi et al. (2011) analysed the insurance market in Central, Eastern and Southeastern Europe and both countries which were analyzed in this research are contained in the sample. They used panel regression (a cross section with fixed effects) to examine the impact of GDP growth on insurance premium growth. The results suggest that economic development and catching-up processes mainly condition premium growth, and that in unstable periods, it shows increased volatility.

\section{COMPARATIVE ANALYSIS OF THE INSURANCE MARKET}

Figure 1 shows the total number of insurance companies operating in the insurance market in Serbia as well as in Bosnia and Herzegovina in the last ten years. The largest number of insurance companies in Serbia was present in the period 2011-2013 when there were 28 companies, followed by the decline in the number of insurance companies, ranging from 25 in 2014 to 21 at the end of 2017.

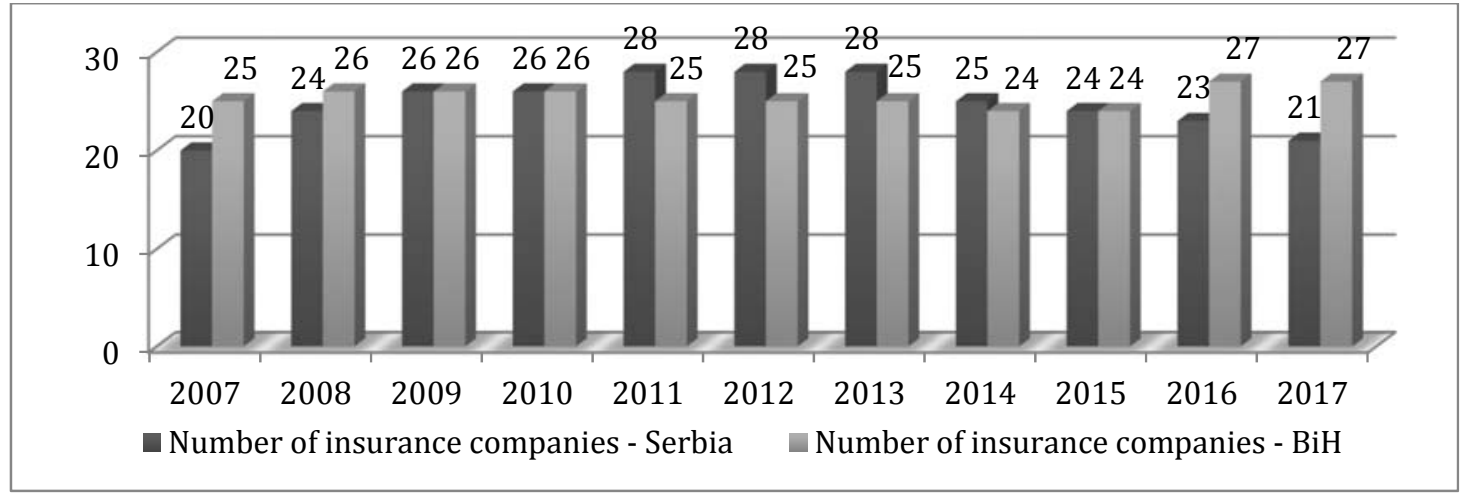

Figure 1. Number of insurance companies, 2007-2017

With the number of insurance companies in the market in Bosnia and Herzegovina, fewer oscillations can be noted in the observed period, ranging from 24 to 27 . The largest number of 
insurance companies at the $\mathrm{B} \& \mathrm{H}$ market operated in the last two years of the observed period, i.e. 2016-2017 with a total of 27 companies.

In addition to the banking sector with the largest share of the balance sheet total in the total financial sector - about $90 \%$, the balance sheets of the leasing companies, pension funds and insurance companies are included. Figure 2 shows a fall in the share of the insurance sector's balance sheet total in the total financial sector, which is notable in both markets in the period 2005-2008. After 2008, the share of the insurance sector balance sheet total in Serbia rose from $4.2 \%$ in 2008 to $6.3 \%$ in 2017. The same trend is present in the insurance market of Bosnia and Herzegovina, where the growth of the balance sheet total in the total financial sector increased in the same period for the same percentage $-2.1 \%$, from $3.45 \%$ to $5.57 \%$ in 2017 .

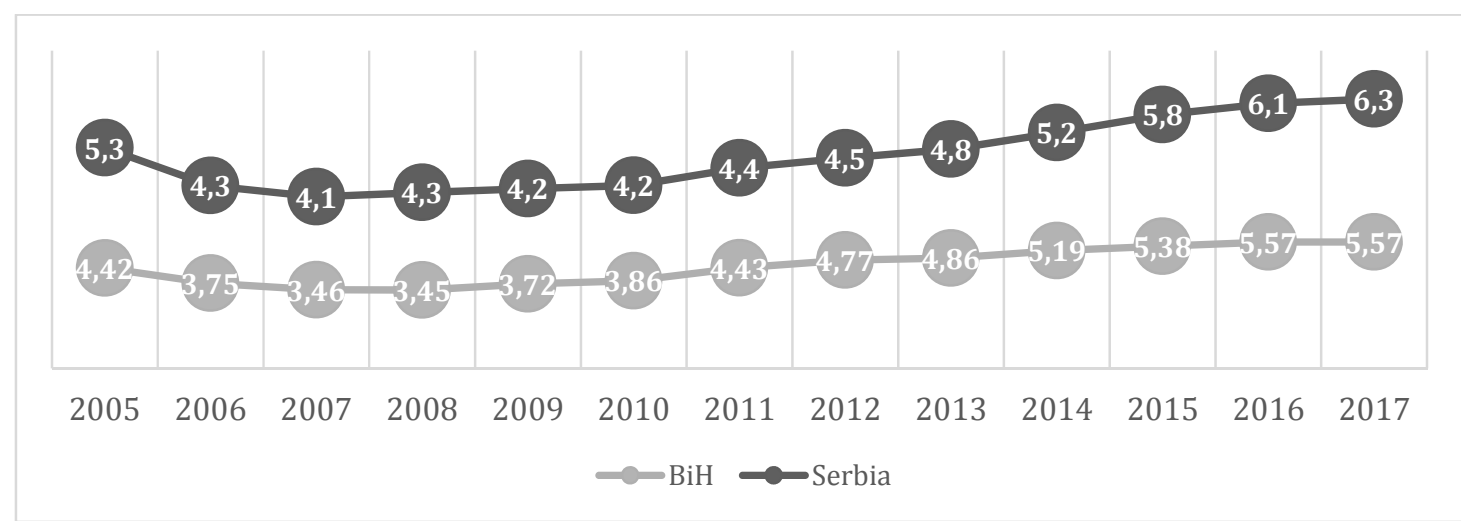

Figure 2. Contribution of the balance sheet total of the insurance sector to the overall financial sector, 2005-2017

Figures 3 and 4 show the ratio of the total number of insurance companies and foreign companies in the period 2007-2017. It can be concluded that the number of foreign insurance companies in Serbia has changed proportionally with the total number of companies present in the market. The number of foreign companies in the insurance market of B\&H did not change significantly in the observed period. There were 10 foreign insurance companies in the period 2008-2014, after which this number increased to 11 and 12 in 2015, 2016 and 2017, respectively.

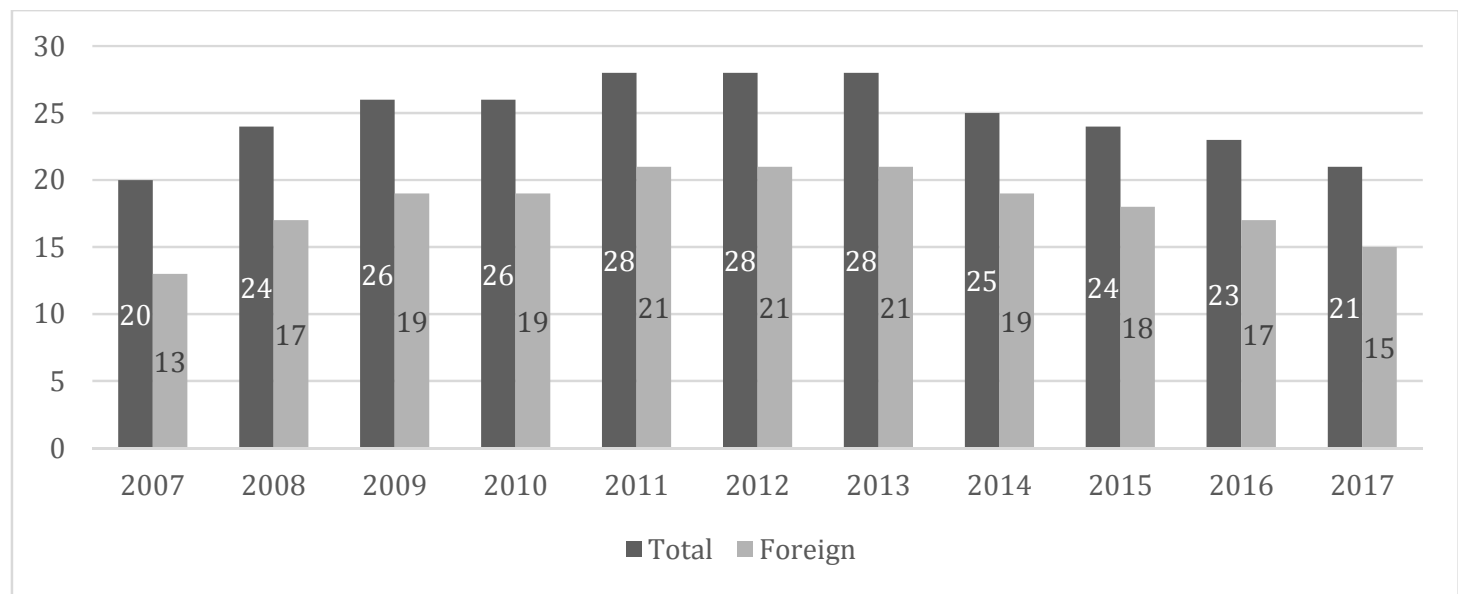

Figure 3. Relationship between the total number of insurance companies and foreign companies, 2007-2017, Serbia 


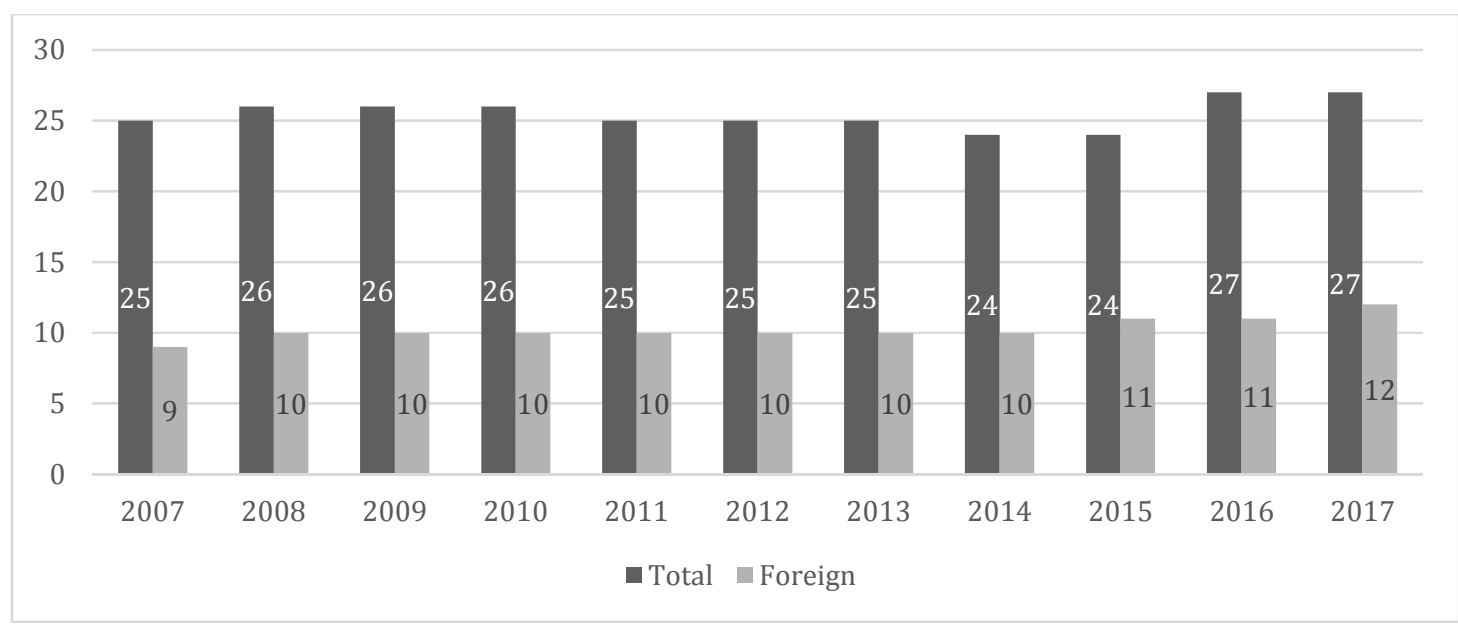

Figure 4. Relationship between the total number of insurance companies and foreign companies, 2007-2017, B\&H

Given that the subject matter of the analysis is the amount of income earned by insurance companies, the companies' market shares are calculated on the basis of the amount of total premiums at the end of the year taken from the balance sheet of insurance companies. Figure 5 shows a comparative analysis of the concentration of the largest companies in B\&H and Serbia according to the criterion of the total balance sheet. Dunav insurance company was the market leader in Serbia according to the mentioned criterion and has absorbed about one-quarter of the entire market in the observed period. By the end of 2015, Sarajevo Insurance was the market leader in $\mathrm{B} \& \mathrm{H}$ according to the criterion of the total premium. For the next two years of the observed period, Uniqa insurance achieved the largest amount of total premiums. The concentration of leader ratio in B\&H is much lower than in Serbia, so the leader in this market has a share of about one-tenth of the entire market.

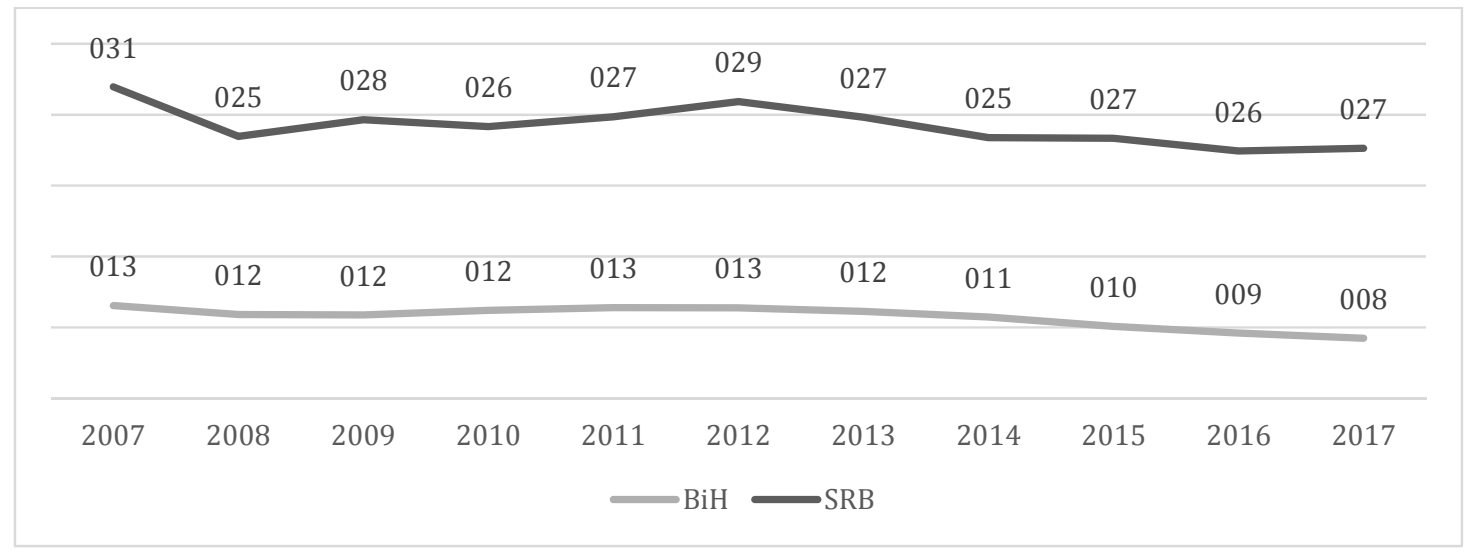

Figure 5. CR1 according to the criterion of the total premium, 2007-2017

The number of companies involved in the calculation of this indicator is determined by government agencies that are monitoring the degree of bid concentration in that particular country, provided that this coefficient is used as an official indicator (Martin, 2002). CR 1, CR3 and CR5 are most frequently accrued in the reports of the responsible insurance institutions, according to the criterion of total premiums, total non-life insurance premiums and total life 
assurance premiums. Figure 6 shows the concentration ratio of the top five insurance companies with the highest total premium. Although there is a mild tendency of market penetration at both markets, at the Serbian insurance market, the first five insurance companies have a much larger share than it is the case in Bosnia and Herzegovina. (as can be seen in Lorenz curves 8 and 9). CR5 had fallen from $84.16 \%$ in 2007 to $77.19 \%$ in 2017 . The mentioned concentration ratio in B\&H dropped from $45.97 \%$ to $39.21 \%$, from 2007 to 2017.

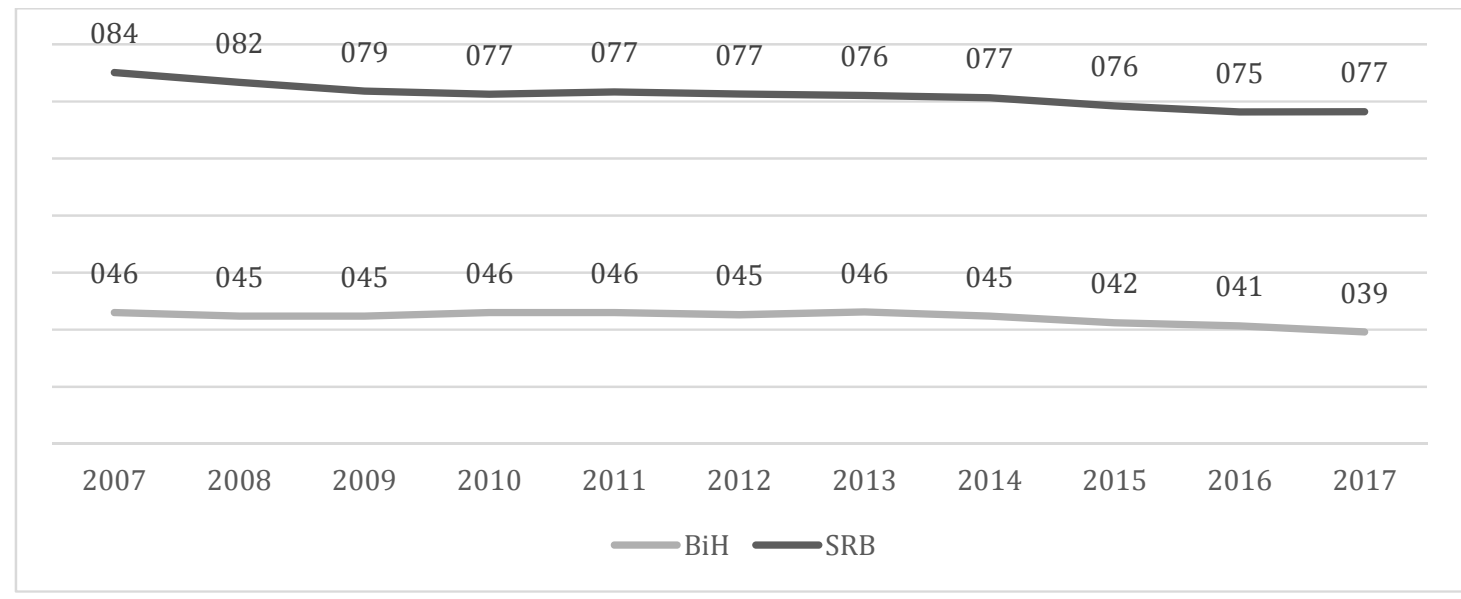

Figure 6. CR5 according to the criterion of the total premium, 2007-2017

Figure 7 shows the dynamic analysis of the Herfindahl-Hirschman index in the period 20072017 for both markets. The significance of the index is reflected in the fact that although it respects the individual market share of all companies in the branch it particularly responds to the presence of companies with large market participations, which significantly increase its value (Lipczynski \& Wilson, 2001) Given the above and taking into account the high CR5 concentration ratio on the insurance market of the Republic of Serbia, high values of the Herfindahl-Hirschman index are not surprising.

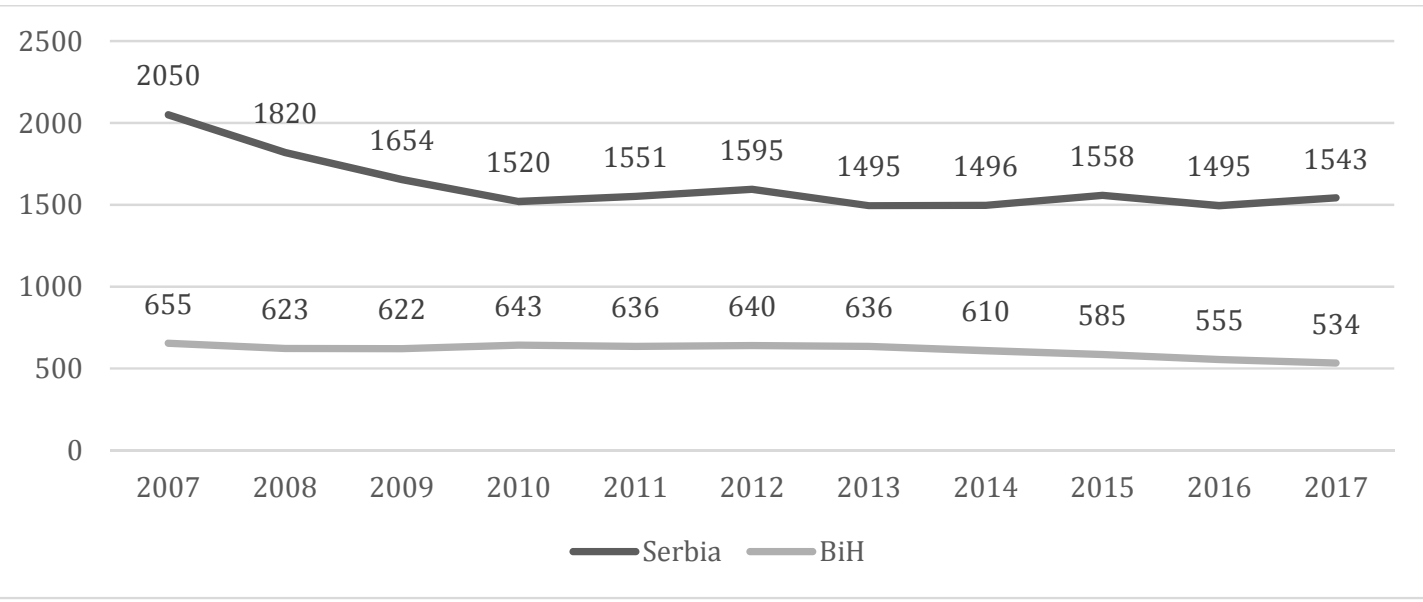

Figure 7. Herfindahl-Hirschman index according to the criterion of the total premium, 2007-017

With the increase in the number of insurance companies in Serbia, this index has declined, so the highly concentrated bid with the index of 2050 in 2007 reached the level of a medium concentrated bid (it is considered thin the market is medium concentrated if the HHI index value 
ranges from 1000 to 1800). It can be concluded that from 2008 until today, the insurance market in Serbia is medium concentrated. Herfindahl-Hirschman index according to the criterion of the total premium differs significantly in the market of Bosnia and Herzegovina, where the permanent low-concentration bid is present in the observed period. Although the HHI index fell from 655 to 534, from 2007 to 2017, it can be concluded that the insurance market in $\mathrm{B} \& \mathrm{H}$ is inconsistent, i.e. that there is greater equality of market share compared with the high inequality among market participants in the insurance sector of the Republic of Serbia.

Figure 8 shows Lorenz curves based on the amount of total premiums for the initial and the last year of the observed period, i.e. 2007 and 2017. First, insurance market leaders have reduced their market share, i.e. the top $20 \%$ of insurance companies in 2007 had a cumulative $80 \%$ of the total market share measured by the total premium, while the same percentage of leaders in 2017 had less than 60\%. With the exception of market leaders (the first four companies) of 18 companies in 2007, 14 companies shared $18.85 \%$ of the total market, while in the year 2017 some 15 companies shared 18.69\%, which suggests that the number of companies increased in the market with smaller market share, primarily due to the appearance of new companies in the market. This finding contributes to the value of the Herfindahl-Hirschman index as well as the value of CR5.
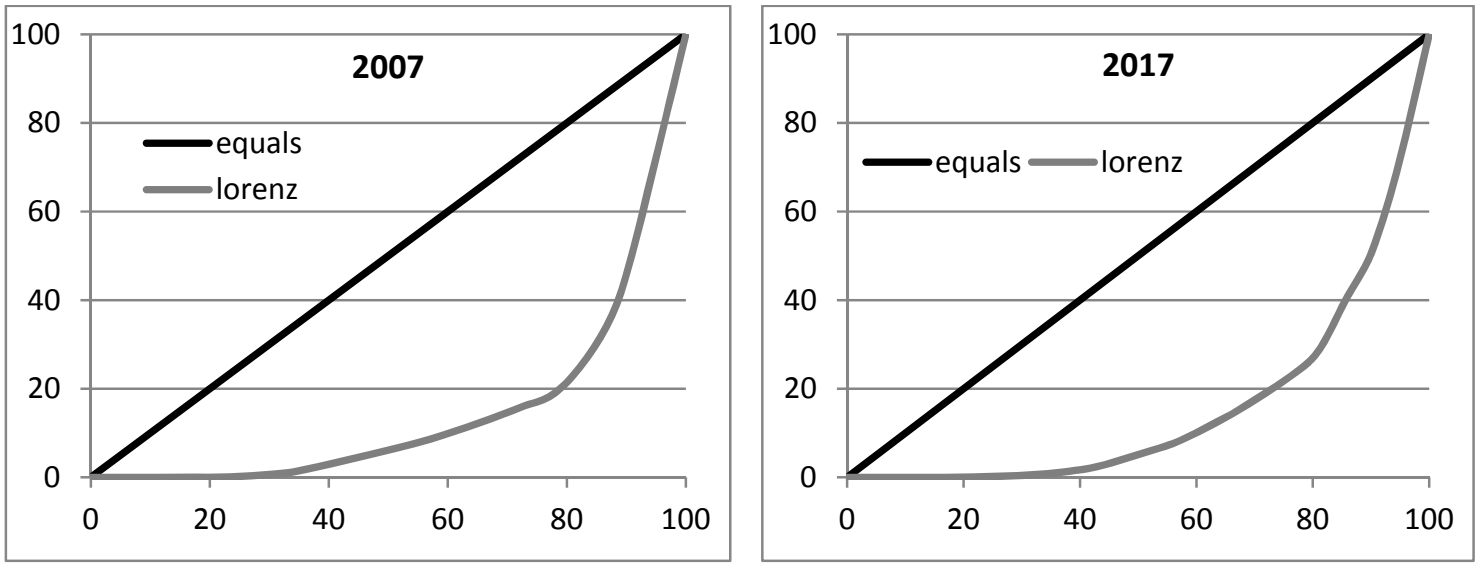

Figure 8. Lorenz curve and Herfindahl-Hirschman index according to the criterion of the total premium, 2007-2017, Serbia

Constructing Lorenz's curve in terms of the degree of concentration of supply in the relevant market, the distribution of the entire market between business entities can be clearly seen. (Kaličanin \& Hanić 2016b). Lorenz curves for the insurance market of Bosnia and Herzegovina constructed based on the premiums shown in Figure 9 differ considerably from those presented in Figure 8. The distribution of the market share of insurance companies in the stipulated market is characterised by greater equality, which can be inferred from the Lorenz curve distance from the equal's curves (in case of equal distribution of market share among all participants in the market). Fewer companies have been able to increase their market share over the observed period, while market leaders reduced their cumulative market share. 

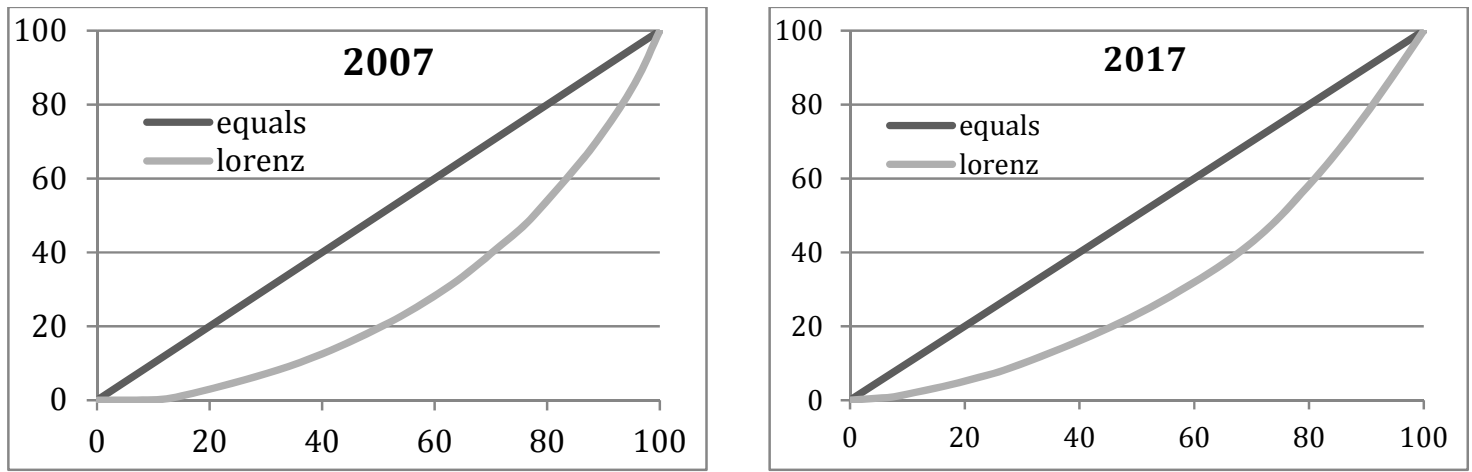

Figure 9. Lorenz curve and Herfindahl-Hirschman index according to the criterion of the total premium, 2007-2017, B\&H

In 2017 in Bosnia and Herzegovina, there were 27 companies, i.e. 6 companies more than in the Republic of Serbia. In addition to the difference in the number of companies, there is greater inequality in the distribution of market shares in the Serbian insurance market as well as greater concentration on the supply side compared to the low concentration of the insurance market of Bosnia and Herzegovina.

\section{METHODOLOGY}

As emphasised before, the aim of this paper is to analyse the insurance market in Serbia and Bosnia and Herzegovina with reference to certain macroeconomic indicators that play a key role in the development of insurance. In this respect, we investigated the mutual influence of individual variables on the movement of total premium income earned in these countries. In this analysis, a time series is used for the period 2000-2017, i.e. for a period of 18 years. For the mentioned period, the following independent variables were analysed:

- $X_{1}$ - Average net salary (current, RSD/KM)

- $X_{2}$ - Unemployment, total (\% of the otal labor force)

- $X_{3}$ - Gross domestic income (constant LCU)

- $X_{4}$ - GDP per capita (current US\$)

- $X_{5}$ - Wage and salaried workers, total (\% of total employment)

- $X_{6}$ - Households and NPISHs Final consumption expenditure (current US\$)

while the dependent variable $Y$ was - Total premium (current RSD/KM).

For this research, multiple regression analysis was carried out using the SPSS statistical software.

The choice of independent variables is based on empirical fundaments that relate to the studied variable, as well as on the information contained in the relevant literature. Six independent variables were included in the analysis to identify those that could explain the major part of the variability of the studied (dependent) variables. A model involving variables whose calculated regression coefficient is significant at $5 \%$ level is selected.

\section{EMPIRICAL RESEARCH AND DISCUSSION}

Usually, the first part of the study contains basic indicators of descriptive statistics. Since all variables included in the analysis were measured on the ratio scale, the values of arithmetic mean and standard deviations are presented as indicators of a descriptive statistic (Table 1 and Table 2). 
Table 1: Descriptive statistics for different variables - Serbia

\begin{tabular}{|l|r|r|r|}
\hline & \multicolumn{1}{|c|}{ Mean } & \multicolumn{1}{c|}{ Std. Deviation } & N \\
\hline Total premium & 49372718.5000 & 24831359.35237 & 18 \\
\hline Average net salary & 345729.3333 & 183811.84680 & 18 \\
\hline $\begin{array}{l}\text { Unemployment, total (\% of total labor } \\
\text { force) }\end{array}$ & 17.6239 & 3.61340 & 18 \\
\hline Gross domestic income (constant LCU) & 2855342777777.7780 & 458570337497.97485 & 18 \\
\hline GDP per capita (current US\$) & 4614.9873 & 1798.25314 & 18 \\
\hline $\begin{array}{l}\text { Wage and salaried workers, total (\% of } \\
\text { total employment) }\end{array}$ & 69.4582 & 1.98410 & 18 \\
\hline $\begin{array}{l}\text { Households and NPISHs Final } \\
\text { consumption expenditure (current US\$) }\end{array}$ & 25301236558.1667 & 9670960437.31504 & 18 \\
\hline
\end{tabular}

Source: Authors using SPSS

Table 2: Descriptive statistics for different variables - BiH

\begin{tabular}{|l|r|r|r|}
\hline & \multicolumn{1}{|c|}{ Mean } & \multicolumn{1}{|c|}{ Std. Deviation } & N \\
\hline Total premium & 430206288.0000 & 141434498.99548 & 18 \\
\hline Average net salary & 1035.7778 & 262.30260 & 18 \\
\hline $\begin{array}{l}\text { Unemployment, total (\% of total labor } \\
\text { force) }\end{array}$ & 27.3079 & 2.00943 & 18 \\
\hline Gross domestic income (constant LCU) & 24073220032.1667 & 3036558289.97812 & 18 \\
\hline GDP per capita (current US\$) & 3848.6667 & 1366.86275 & 18 \\
\hline $\begin{array}{l}\text { Wage and salaried workers, total (\% of } \\
\text { total employment) }\end{array}$ & 66.5221 & 6.48730 & 18 \\
\hline $\begin{array}{l}\text { Households and NPISHs Final } \\
\text { consumption expenditure (current US\$) }\end{array}$ & 12811176132.8333 & 2684992943.38614 & 18 \\
\hline
\end{tabular}

Source: Authors using SPSS

Below is an output that refers to the multiple regression model which was implemented on the data obtained for both countries involved in the analysis.

Table 3: Model summary along with the values of R and R square - Serbia

\begin{tabular}{|c|c|c|c|c|c|c|c|c|c|}
\hline \multirow[b]{2}{*}{ Model } & \multirow[b]{2}{*}{$\mathbf{R}$} & \multirow{2}{*}{$\begin{array}{c}\text { R } \\
\text { Square }\end{array}$} & \multirow{2}{*}{\begin{tabular}{|c} 
Adjusted \\
R \\
Square
\end{tabular}} & \multirow{2}{*}{$\begin{array}{l}\text { Std. Error of } \\
\text { the Estimate }\end{array}$} & \multicolumn{5}{|c|}{ Change Statistics } \\
\hline & & & & & $\begin{array}{c}\text { R Square } \\
\text { Change }\end{array}$ & $\begin{array}{c}\text { F } \\
\text { Change }\end{array}$ & df1 & df2 & $\begin{array}{c}\text { Sig. F } \\
\text { Change }\end{array}$ \\
\hline 1 & $.962^{a}$ & .925 & .920 & 7023512.91992 & .925 & 196.491 & 1 & 16 & .000 \\
\hline 2 & $.981^{b}$ & .962 & .957 & 5152189.94256 & .037 & 14.733 & 1 & 15 & .002 \\
\hline 3 & $.992^{c}$ & .983 & .980 & 3548389.97989 & .021 & 17.624 & 1 & 14 & .001 \\
\hline 4 & $.996^{\mathrm{d}}$ & .993 & .990 & 2444365.32992 & .009 & 16.502 & 1 & 13 & .001 \\
\hline
\end{tabular}

a. Predictors: (Constant), Average net salary

b. Predictors: (Constant), Average net salary, Households and NPISHs Final consumption expenditure (current US\$)

c. Predictors: (Constant), Average net salary, Households and NPISHs Final consumption expenditure (current US\$), Gross domestic income (constant LCU)

d. Predictors: (Constant), Average net salary, Households and NPISHs Final consumption expenditure (current US\$), Gross domestic income (constant LCU), Unemployment, total (\% of total labor force)

Source: Authors using SPSS 
In the case of variables describing the insurance market in the Republic of Serbia, four models were generated, where the last model was selected having the highest value of the coefficient $R^{2}$. The $R^{2}$ value in this case shows that $99.3 \%$ variations in total premium can be explained by selected four variables and this model can be considered appropriate to develop the regression equation. The independent variables selected by the above mentioned model are as follows: Average net salary, Households and NPISHs Final consumption expenditure, Gross domestic income and Unemployment, total (Table 3).

The following table shows the unstandardized and standardised regression coefficients for all models. In the last model, t-values for all the two regression coefficients are significant as their significance values ( $p$-values) are less than 0.05. Therefore, it can be concluded that the previously selected 4 independent variables significantly explain the variations in the total premium.

Table 4: Regression coefficients of selected variables in different models along with their $t$ values and partial ccorrelations - Serbia

\begin{tabular}{|c|c|c|c|c|c|c|c|c|c|}
\hline & \multirow{2}{*}{ Model } & \multicolumn{2}{|c|}{ Unstandardized Coefficients } & \multirow{2}{*}{\begin{tabular}{|c|}
$\begin{array}{c}\text { Standardised } \\
\text { Coefficients }\end{array}$ \\
Beta \\
\end{tabular}} & \multirow[b]{2}{*}{$\mathbf{t}$} & \multirow{2}{*}{ Sig. } & \multicolumn{3}{|c|}{ Correlations } \\
\hline & & B & Std. Error & & & & $\begin{array}{l}\text { Zero- } \\
\text { order }\end{array}$ & Partial & Part \\
\hline \multirow[t]{2}{*}{1} & (Constant) & 4460520.406 & 3606405.932 & & 1.237 & .234 & & & \\
\hline & Average net salary & 129.906 & 9.267 & .962 & 14.018 & .000 & .962 & .962 & .962 \\
\hline \multirow[t]{3}{*}{2} & (Constant) & 14150355.208 & 3656718.281 & & 3.870 & .002 & & & \\
\hline & Average net salary & 178.058 & 14.268 & 1.318 & 12.479 & .000 & .962 & .955 & .628 \\
\hline & $\begin{array}{l}\text { Households and } \\
\text { NPISHs Final } \\
\text { consumption } \\
\text { expenditure }\end{array}$ & -.001 & .000 & -.405 & -3.838 & .002 & .753 & -.704 & -.193 \\
\hline \multirow[t]{4}{*}{3} & (Constant) & -66019515.273 & 19262250.240 & & -3.427 & .004 & & & \\
\hline & Average net salary & 102.779 & 20.448 & .761 & 5.026 & .000 & .962 & .802 & .174 \\
\hline & $\begin{array}{l}\text { Households and } \\
\text { NPISHs Final } \\
\text { consumption } \\
\text { expenditure }\end{array}$ & -.002 & .000 & -.640 & -6.977 & .000 & .753 & -.881 & -.242 \\
\hline & $\begin{array}{l}\text { Gross domestic } \\
\text { income }\end{array}$ & $4.254 \mathrm{E}-5$ & .000 & .786 & 4.198 & .001 & .934 & .747 & .145 \\
\hline \multirow[t]{5}{*}{4} & (Constant) & -49098413.472 & 13907538.352 & & -3.530 & .004 & & & \\
\hline & Average net salary & 107.565 & 14.135 & .796 & 7.610 & .000 & .962 & .904 & .182 \\
\hline & $\begin{array}{l}\text { Households and } \\
\text { NPISHs Final } \\
\text { consumption } \\
\text { expenditure } \\
\end{array}$ & -.001 & .000 & -.550 & -8.200 & .000 & .753 & -.915 & -.196 \\
\hline & $\begin{array}{l}\text { Gross domestic } \\
\text { income }\end{array}$ & $3.880 \mathrm{E}-5$ & .000 & .717 & 5.512 & .000 & .934 & .837 & .132 \\
\hline & $\begin{array}{l}\text { Unemployment, } \\
\text { total (\% of total } \\
\text { labor force) }\end{array}$ & -783350.327 & 192833.041 & -.114 & -4.062 & .001 & .250 & -.748 & -.097 \\
\hline
\end{tabular}

a. Dependent Variable: Total premium

Source: Authors using SPSS

Using the values of the unstandardized regression coefficients of the last model presented in Table 4, the following regression model can be shown:

Total premium

$$
\begin{aligned}
& =-49098413.472+107.565 \text { Average net salary } \\
& -0.001 \text { Households and NPISHs Final consumption expenditure } \\
& +0.0000388 \text { Gross domestic income }-783350.327 \text { Unemployment total }
\end{aligned}
$$


Concerning the same analysis carried out for the data from Bosnia and Herzegovina, two models were generated, where the second one was selected for which the value of 0.983 was assigned for the determination coefficient (Table 5). In this way, a multiple hierarchy model was formulated which combines two independent variables as follows: Gross domestic income and Wage and salaried workers, total. Since the F-value for this model is highly significant, the model is reliable. Also, the regression coefficients in the stipulated model are statistically significant, and it is considered that the selected variables have a great predictive significance in estimating the value of the Total premium.

Table 5: Model summary along with the values of R and R square - BIH

\begin{tabular}{|c|c|c|c|c|c|c|c|c|c|}
\hline \multirow[b]{2}{*}{ Model } & \multirow[b]{2}{*}{$\mathbf{R}$} & \multirow[b]{2}{*}{$\begin{array}{c}\mathbf{R} \\
\text { Square }\end{array}$} & \multirow[b]{2}{*}{$\begin{array}{l}\text { Adjusted R } \\
\text { Square }\end{array}$} & \multirow[b]{2}{*}{$\begin{array}{l}\text { Std. Error of the } \\
\text { Estimate }\end{array}$} & \multicolumn{5}{|c|}{ Change Statistics } \\
\hline & & & & & $\begin{array}{c}\text { R Square } \\
\text { Change }\end{array}$ & \begin{tabular}{|c|}
$\mathbf{F}$ \\
Change
\end{tabular} & df1 d & df2 & $\begin{array}{c}\text { Sig. F } \\
\text { Change }\end{array}$ \\
\hline 1 & $.975^{\mathrm{a}}$ & .951 & .948 & 32128444.21790 & .951 & 313.443 & 1 & 16 & .000 \\
\hline 2 & $.992^{b}$ & .983 & .981 & 19491967.96979 & .032 & 28.470 & 1 & 15 & .000 \\
\hline
\end{tabular}

a. Predictors: (Constant), Gross domestic income (constant LCU)

b. Predictors: (Constant), Gross domestic income (constant LCU), Wage and salaried workers, total (\% of total employment)

Source: Authors using SPSS

The last table contains the values of the regression coefficients for the previously selected model.

Table 6: Regression coefficients of selected variables in different models along with their $t$ values and partial correlations - BIH

\begin{tabular}{|c|c|c|c|c|c|c|c|c|c|}
\hline \multirow{2}{*}{\multicolumn{2}{|c|}{ Model }} & \multicolumn{2}{|c|}{$\begin{array}{l}\text { Unstandardized } \\
\text { Coefficients }\end{array}$} & \multirow{2}{*}{\begin{tabular}{|c|}
$\begin{array}{c}\text { Standardised } \\
\text { Coefficients }\end{array}$ \\
Beta \\
\end{tabular}} & \multirow{2}{*}{$\mathbf{t}$} & \multirow{2}{*}{ Sig. } & \multicolumn{3}{|c|}{ Correlations } \\
\hline & & B & Std. Error & & & & $\begin{array}{l}\text { Zero- } \\
\text { order }\end{array}$ & Partial & Part \\
\hline 1 & (Constant) & -663490820.738 & 62238137.572 & & -10.661 & .000 & & & \\
\hline & $\begin{array}{l}\text { Gross domestic } \\
\text { income }\end{array}$ & .045 & .003 & .975 & 17.704 & .000 & .975 & .975 & .975 \\
\hline 2 & (Constant) & -827546449.311 & 48694106.929 & & -16.995 & .000 & & & \\
\hline & $\begin{array}{l}\text { Gross domestic } \\
\text { income }\end{array}$ & .035 & .002 & .759 & 14.452 & .000 & .975 & .966 & .483 \\
\hline & $\begin{array}{l}\text { Wage and } \\
\text { salaried } \\
\text { workers, total } \\
\text { (\% of total } \\
\text { employment) }\end{array}$ & 6110923.803 & 1145287.155 & .280 & 5.336 & .000 & .866 & .809 & .178 \\
\hline
\end{tabular}

a. Dependent Variable: Total premium

Source: Authors using SPSS

Regression equation, which can explain the variability of the observed Total premium variable analysing trends in selected independent variables goes as follows:

Total premium

$=-827546449.311+0.035$ Gross domestic income
+6110923.803 Wage and salaried workers 


\section{CONCLUSION}

After 2008, the share of the insurance sector balance sheet total in Serbia and Bosnia and Herzegovina increased in the same period for the same percentage $-2.1 \%$. The number of insurance companies with foreign equity in Serbia has changed proportionally with the total number of companies present in the market whereas the number of the foreign insurance companies in Bosnia and Herzegovina remained almost the same although the total number of the insurance companies increased. The concentration of leader ratio (CR1) in Bosnia and Herzegovina is much lower than in Serbia, so the leader in this market has a share of about $10 \%$ of the entire market while in Serbia it is about $27 \%$. Although there is a moderate tendency of market penetration at both markets, at the Serbian insurance market, the first five insurance companies have a much larger share than it is the case in Bosnia and Herzegovina. It can be concluded that in the last decade the insurance market in Serbia is medium concentrated according to Herfindahl-Hirschman index calculated by total premium and it differs significantly in the market of Bosnia and Herzegovina, where permanent low-concentration bid is present in the observed period - there is greater equality of market share compared with the high inequality among market participants in the insurance sector of the Republic of Serbia.

In this paper, the multi-linear regression model was applied in order to analyse the impact of selected macroeconomic indicators on the amount of insurance premiums in the period 20002017. We can conclude that the greatest impact on the amount of the premium in Bosnia and Herzegovina had Gross Domestic Income and Wage and Salaries Workers. In the Republic of Serbia, the greatest influence on the amount of premium in the observed period had Average Net Salary, Households and Final Consumption Expenditure and Gross Domestic Income. Therefore, there is a positive correlation between household income (including salary and other income) and premiums. Also, in the periods when household expenditure was higher, the amount of total insurance premium was also higher.

Both of the selected economies have undergone changes in the financial sector, particularly in terms of recent regulatory reforms. This paper provides information on the determinants of insurance demand in the Republic of Serbia and Bosnia and Herzegovina. This research is limited to a macro level analysis of the insurance demand. Further, detailed analysis can be performed on individual life insurance products, which may result in more reliable findings. The period 2000-2017 was analysed, so future studies can further segregate the CEE region into developed and developing economies and make a detailed time series analysis incorporating both pre-crisis and post-crisis period.

\section{ACKNOWLEDGEMENTS}

This paper is a result of research projects under the code 179015 (Challenges and Prospects of Structural Changes in Serbia: Strategic Directions for Economic Development and harmonisation with EU requirements) financed by the Ministry of Science and Technological Development of the Republic of Serbia.

\section{REFERENCES}

Beck, T. \& Webb, I. (2003). "Economic, demographic and institutional determinants of life insurance consumption", The World Bank Economic Review, 17(1): 51-88., doi: 10.1093/wber/lhg011.

Bianchi, T., Ebner, G., Korherr, R. \& Ubl, E. (2011). "The Austrian Insurance Industry in CESEE: Risks and Opportunities from a Financial Stability Point of View." Financial Stability Report 22 [Internet], pp. 88-106. Available at: https://www.researchgate.net/profile/Eva_Ubl/publication/227462654_The_Austrian_Insur 
ance_Industry_in_CESEE_Risks_and_Opportunities_from_a_Financial_Stability_Point_of_View/l inks/0deec53b4fe428fd37000000.pdf (Accessed: 28 March 2019).

Burić Novović, M., Cerović Smolović, J., Lipovina Božović, M. \& Lalević Filipović, A. (2017). "Impact of economic factors on life insurance development in Western Balkan Countries." Zbornik radova Ekonomskog fakulteta $u$ Rijeci 35, br. 2: 331-352. https://doi.org/10.18045/zbefri.2017.2.331.

Dragos, S. (2014). "Life and non-life insurance demand: the different effects of influence factors in emerging countries from Europe and Asia". Economic Research Ekonomska Istraživanja, 27(1): 169-180, doi: 10.1080/1331677x.2014.952112.

Haiss, P. \& Sümegi, K. (2008). "The relationship between insurance and economic growth in Europe: a theoretical and empirical analysis" Empirica, 35(4): 405-431, doi: 10.1007/s10663008-9075-2.

Kaličanin, T. \& Hanić, A. (2016a). "Comparative Analysis of Levels of Banking Sector Markets Concentration in CEE Region." Economic Analysis, 49(1-2) 59-72.

Kaličanin, T. \& Hanić, A. (2016b). "Analiza koncentracije u finansijskom sektoru." In: Pravci strukturnih promena u procesu pristupanja Evropskoj uniji, ed. Minović, Jelena, Duško Bodroža, Ivan Stošić, and Božo Drašković, 308-324. Belgrade: Institute of economic sciences.

Kaličanin, T. \& Lazić, M. (2018). "Evaluating the Level of Market Concentration in Insurance Sector: the case of Serbia." In: Western Balkans Economies in EU Integration, past, present and future, ed. Richet, Xavier, Dejan Erić, Srđan Redžepagić, Ivan Stošić and Duško Bodroža, 202221. Nice: CEMAFI International Association.

Kjosevski, J. (2012). "The determinants of life insurance demand in central and Southeastern Europe". International Journal of Economics and Finance, 4(3): pp. 237-247, doi: $10.5539 /$ ijef.v4n3p237.

Lipczynski, J. \& John, W. (2001). Industrial Organization: An Analysis of Competitive Markets. Prentice-Hall, London.

Martin, S. (2002). Advanced Industrial Economics. Blackwell Publishers Ltd, Oxford.

Mitra, A. (2017). "Influencers of Life Insurance Investments: Empirical Evidence from Europe". Australasian Accounting, Business and Finance Journal, 11(3): 87-102. https://doi.org/10.14453/aabfj.v11i3.7.

Outreville, F. (1990). "The Economic Significance of Insurance Markets in Developing Countries." The Journal of Risk and Insurance 57, no. 3: 487-98. doi:10.2307/252844.

Ward, D. \& Zurbruegg, R. (2002). "Law, Politics and Life Insurance Consumption in Asia", Geneva Papers on Risk and Insurance, 27(3): 395-412. doi:10.1111/1468-0440.00181.

Webb, I., Martin, G. \& Skipper, H. (2002). "The Effect of Banking and Insurance on the Growth of Capital and Output". Centre for Risk Management and Insurance, Working Paper, No. 02-1. Robinson College of Business, Georgia State University, Atlanta.

Zhi, Z. (1998). Die Nachfrage nach Lebensversicherungen: Eine empirische Analyse für China, Mannheimer Manuskripte zu Risikotheorie, Portfolio Management und Versicherungswirtschaft 112, Universität Mannheim.

www.nbs.rs

www.azobih.gov.ba

www.data.worldbank.org

Article history: $\quad$ Received: April 1, 2019

Accepted: May 29, 2019 